\title{
A crise Baring e a crise do Encilhamento nos quadros da economia-mundo capitalista ${ }^{1}$
}

\author{
Felipe Amin Filomeno ${ }^{2}$
}

\begin{abstract}
Resumo
O final do século XIX foi marcado, para Brasil e Argentina, por crescimento e instabilidade na economia. Neste período, ocorreram duas importantes crises econômicas, que ficaram conhecidas como crise Baring (na Argentina) e crise do Encilhamento (no Brasil). Este artigo tem o objetivo de apresentar as conexões existentes entre essas duas crises e a conjuntura da economia-mundo capitalista das últimas décadas do século XIX, enfatizando o problema da dívida externa e da política econômica, e re-organizando algumas contribuições da historiografia econômica por meio da metodologia da "encompassing comparison" e da teoria dos ciclos mundiais de endividamento. O artigo mostra que ambas as crises estiveram condicionadas pela dinâmica da economia-mundo capitalista, especialmente pelos fluxos mundiais de capital, não sendo resultados exclusivos de políticas econômicas nacionais.
\end{abstract}

Palavras-chave: Crise Baring; Encilhamento; Economia - Argentina; Economia - Brasil.

\begin{abstract}
The Baring Crisis and the Encilhamento Crisis in the context of the capitalist world-economy

The end of the $19^{\text {th }}$ century was characterized by economic growth and instability in Brazil and Argentina. In this period, two important economic crises took place - the Baring Crisis (in Argentina) and the Encilhamento Crisis (in Brazil). The aim of this paper is to present the connections between these two crises and the dynamics of the capitalist world-economy of the end of the $19^{\text {th }}$ century, focusing on the problems of external debt and economic policy and re-organizing some contributions of economic historiography through the methodology of "encompassing comparison" and of the world debt cycles' theory. The paper concludes that both crises were influenced by the dynamics of the capitalist world-economy, especially by the international flows of capital, and that they were not exclusive results of national economic policies.
\end{abstract}

Key words: Baring Crisis; Encilhamento; Argentine economy; Brazilian economy.

JEL N160.

\section{Introdução}

O final do século XIX foi marcado, para Brasil e Argentina, por crescimento e instabilidade na economia. Neste período, ocorreram duas importantes crises econômicas, que ficaram conhecidas como crise Baring (na Argentina) e crise do Encilhamento (no Brasil). Este artigo tem o objetivo de

(1) Trabalho recebido em julho de 2007 e aprovado em fevereiro de 2009.

(2) Doutorando em Sociologia na Johns Hopkins University (EUA), como bolsista Capes-Fulbright, desde setembro de 2007, Baltimore, EUA. E-mail: <aminfilomeno@gmail.com>. O autor agradece os comentários de Pedro Antonio Vieira (Universidade Federal de Santa Catarina, SC, Brasil). 
apresentar as conexões existentes entre essas duas crises e a conjuntura da economia-mundo capitalista das últimas décadas do século XIX, enfatizando o problema da dívida externa e da política econômica.

$\mathrm{Na}$ historiografia econômica argentina e brasileira, a influência da economia internacional sobre a crise Baring e a crise do Encilhamento tem sido considerada inegável. Porém, segundo Kindleberger (1985, p. 231), "um problema geral tem sido que parcela de culpa pelas crises atribuir aos eventos internacionais". Segundo este autor, "de um ponto de vista monetarista, tende-se a atribuir a crise quase que totalmente aos eventos ocorridos na periferia, especialmente novas leis bancárias introduzidas na Argentina em 1887 e no Brasil em 1888 e eventos políticos como revoluções ou golpes de Estado" (Kindleberger, 1985, p. 231). Por outro lado, a escola do balanço de pagamentos tende a dar mais importância para o comportamento dos fluxos mundiais de capital e seus efeitos sobre a taxa de câmbio (Kindleberger, 1985).

Neste debate, efetivamente, a maior parte dos estudos situa-se em dois extremos: ou um dos dois casos nacionais é enfatizado e a influência da economia internacional (e das conexões entre as duas crises) aparece como um dentre vários determinantes da crise, ou a crise financeira internacional e os efeitos de contágio são destacados e os casos nacionais são abordados apenas superficialmente. Estudos como o de Triner (2001), a saber, em que a análise da dimensão internacional das crises é combinada com um estudo detalhado dos dois casos, são exceção. Neste sentido, o presente artigo segue esta mesma linha de análise para posicionar-se neste debate, ainda que, ao contrário de Triner (2001), considera-se neste trabalho que a dimensão internacional da crise não é restrita ao efeito de contágio da Argentina sobre o Brasil, mas sim refere-se a uma crise mundial de endividamento da periferia da economia-mundo capitalista, da qual a crise Baring e a crise do Encilhamento são dois episódios (ainda que portadores de determinnates nacionais específicos).

Boris Fausto (1989) já havia salientado o papel da conjuntura sistêmica na crise do Encilhamento, utilizando como argumento as semelhanças com a crise Baring. Para ele, a crise econômica ocorrida no Brasil na década de 1890 tem sido excessivamente vinculada às emissões monetárias exacerbadas do período, com menor consideração de outros fatores como, por exemplo, a conjuntura mundial. Segundo o autor, a crise ocorreu, com diferença de alguns anos, tanto no Brasil como na Argentina, levando a pensar não em uma identidade de problemas, mas na intervenção comum de elementos derivados do quadro internacional (Fausto, 1989). Ao final, entretanto, Boris Fausto não desenvolve completamente este argumento - que vem a ser justamente o objetivo do presente trabalho. 
Ademais, não existe (ou não é de nosso conhecimento), até o presente momento, trabalho publicado no Brasil que compare sistematicamente as duas crises. A publicação, em 2007, da pesquisa de Luís Nassif - que compara as reformas monetárias do Plano Real com as do Encilhamento para demonstrar como agentes governamentais e capitalistas locais se aproveitaram da conjuntura de crise para enriquecer - demonstra a atualidade do tema. ${ }^{3}$

Neste sentido, foram reorganizadas, de maneira original, contribuições da historiografia econômica, com o uso da metodologia da "encompassing comparison" e da teoria dos ciclos mundiais de endividamento, a fim de destacar o componente sistêmico-mundial das duas crises. A "encompassing comparison" metodologia específica empregada por Immanuel Wallerstein na análise dos sistemas-mundo - começa com uma grande estrutura ou processo social e depois seleciona casos localizados nesta estrutura ou processo, para então explicar, quando as evidências históricas e a lógica permitem, as similaridades e diferenças encontradas entre os casos como consequências de suas relações com o todo. No presente estudo, considera-se que Argentina e Brasil não são unidades completamente autônomas, paralelas e distintas, mas sim partes integrantes de uma economia-mundo capitalista, ${ }^{5}$ cuja dinâmica singular (aqui representada pelos ciclos mundiais de endividamento) abarca a ambos, embora seja possível produzir resultados diversos em cada uma. Assim, a comparação entre a crise Baring e a crise do Encilhamento é utilizada para se identificar regularidades, semelhanças e padrões que possam ser compreendidos como "reverberações" locais de processos sistêmicos inerentes à economia-mundo capitalista - e, assim, mostrar a dimensão transnacional e sistêmica dos fenômenos locais específicos. Procura-se mostrar que as duas crises estiveram relacionadas e são explicadas, em grande medida (mas não exclusivamente), por processos transnacionais de âmbito sistêmico, não sendo resultantes apenas de fatores nacionais exclusivos de cada caso (como políticas econômicas implementadas por certos governantes, segundo julga a vertente monetarista ortodoxa). ${ }^{6}$

(3) Ver Nassif (2007).

(4) Para maiores detalhes sobre esta metodologia, ver Tilly (1984). Fausto e Devoto (2004) traduziram o termo "encompassing comparison" como "comparação globalizante". Neste texto, optamos por manter a expressão inglesa.

(5) Os Estados-nação são instituições parciais de uma economia global, singular e ampla (Wallerstein, 1983 apud McMichael, 1990).

(6) Destarte, não se está afirmando que a dinâmica da economia-mundo teve resultados idênticos nos dois países, pois seus efeitos foram mediados pelas particularidades da economia política de cada país, nem se afirma que ambos os países foram meras vítimas de um ambiente econômico mundial desfavorável, posto que, como será visto, agentes governamentais e capitalistas locais tiraram proveito dos negócios e políticas econômicas relacionados às crises (cf. Nassif, 2007); esses, porém, como será argumentado, estiveram condicionados por processos sistêmicos de larga escala e longa duração. 
Felipe Amin Filomeno

$\mathrm{Na}$ seção 1, apresenta-se brevemente a teoria dos ciclos mundiais de endividamento e a conjuntura da economia-mundo capitalista do fim do século XIX, destacando-se os fenômenos sistêmicos relativos aos ciclos de endividamento que mais influenciaram as crises Baring e do Encilhamento. A seção 2 é dedicada à crise Baring, enquanto a seção 3 é dedicada à crise do Encilhamento e à identificação de paralelos e contrastes entre as duas crises. Por último, são apresentadas considerações finais com base na análise comparativa realizada.

\section{Ciclos mundiais de endividamento e a economia-mundo capitalista no final do século XIX}

A teoria dos ciclos de endividamento associa a alternância de fases de ascenso e descenso no endividamento externo dos países periféricos aos ciclos longos de Kondratiev. ${ }^{7}$ Embora os autores a ela filiados difiram em alguns aspectos, concordam com a constatação empírica de que a dinâmica da economiamundo capitalista tende a provocar regularmente uma crise da dívida externa nos países periféricos. Esta teoria está expressa em Suter e Pfister (1987), Marichal (1988), Suter (1992), Suter e Stamm (1987), Stewart (1993; 2002) e Toussaint (2003). As contribuições de Stewart são resultado do teste empírico que fez das teorias de Suter e Pfister para o período entre 1782 e a década de 1980. Já as contribuições de Marichal (1988) e Toussaint (2003) estão nas análises históricas que fazem da dívida externa latino-americana, sem, entretanto, avançar muito no desenvolvimento de uma teoria sobre os ciclos de endividamento. Portanto, a teoria apresentada a seguir é basicamente aquela desenvolvida por Suter e Pfister.

Suter (1992) desenvolveu um esquema conceitual para a análise de longo prazo do endividamento externo da periferia e semiperiferia baseado na Análise dos Sistemas-Mundo, ${ }^{8}$ agregando contribuições schumpeterianas e marxistas. Segundo este autor, a dívida externa de Estados periféricos e semiperiféricos, durante os séculos XIX e XX, foi caracterizada por flutuações cíclicas. Sua análise histórica identificou quatro períodos de incapacidade de serviço da dívida externa entre devedores soberanos na periferia e semiperiferia desde 1800. Os picos das crises ocorreram: (i) do fim da década de 1820 ao começo da década de 1840; (ii) de meados da década de 1870 ao início da década de 1880; (iii) do início da década de 1930 ao final da década de 1940; e (iv) na década de 1980. Dois outros

(7) Ciclos econômicos identificados estatisticamente pelo russo Nikolai Kondratiev, em 1926, com duração média de 50 anos e uma fase de expansão e outra de contração da atividade econômica.

(8) Perspectiva de análise histórica e macrosociológica, inaugurada pela obra de Immanuel Wallerstein nos anos 1970, que propõe sistemas sociais históricos (como o sistema-mundo capitalista formado) e a longa duração como coordenadas de análise para o estudo de fenômenos sociológicos. 
picos de crises de endividamento menos pronunciados ocorreram em meados da década de 1890 e nos anos anteriores e durante a Primeira Guerra Mundial.

Suter (1992) associou essas crises mundiais de endividamento aos ciclos de Kondratieff, distinguindo quatro fases nesses ciclos (recuperação, prosperidade, recessão e depressão), que correspondem a quatro estágios de um ciclo de paradigma tecno-econômico, a saber:

Primeira Fase: Um novo ciclo longo emerge com a ocorrência de inovações básicas, que resultarão, por sua vez, num novo paradigma tecnoeconômico, levando à fabricação de produtos novos, altamente demandados e, por isso, lucrativos, assim como a novas estruturas institucionais e sociais. A produção nos setores líderes é altamente intensiva em trabalho e apenas modestamente padronizada. Como a criação de inovações básicas requer a presença de um potencial de inovação importante e de contatos próximos com mercados potenciais de alta renda, o novo ciclo longo geralmente se origina no centro da economiamundo. Nesta fase, as relações financeiras entre centro, periferia e semiperiferia estão parcialmente interrompidas, pois a incapacidade de vários países de arcar com o serviço da dívida externa, originada da crise da dívida externa do ciclo anterior, ainda continua existindo. Por esta razão, os retornos obtidos com ativos financeiros e com investimento estrangeiro são relativamente baixos, promovendo um direcionamento do capital para os setores líderes que prometem altos lucros.

Segunda Fase: À medida que a produção nos setores líderes do ciclo longo alcança a maturidade, via inovações incrementais, ela se consolida num paradigma tecnológico específico daquele ciclo longo, que inclui os pré-requisitos sociais e institucionais da produção, assim como um conjunto amplamente aceito de bens de consumo que representam símbolos de status. Consequentemente, os mercados dos produtos líderes tornam-se mercados de massa e sua produção torna-se progressivamente padronizada e concentrada. Durante este estágio, o ciclo longo expande-se por toda a região central da economia-mundo e a periferia é integrada nesta fase de crescimento, principalmente através do comércio e, secundariamente, pela produção nos setores líderes e pela adoção de estruturas institucionais relevantes para o paradigma tecnológico deste novo ciclo. A demanda crescente na indústria dos países centrais por matérias-primas aumenta os preços dos principais bens de exportação da periferia. $\mathrm{O}$ aumento em suas receitas de exportação permite que os países atingidos pela crise da dívida externa do ciclo anterior selem acordos e solucionem seus problemas com credores. Devido à manutenção da alta lucratividade dos investimentos no centro, os fluxos de capital para a periferia são apenas modestos.

Terceira Fase: O potencial de inovação no paradigma vigente arrefece e os mercados de consumo se tornam saturados no centro da economia-mundo, de 
modo que a taxa de lucro dos investimentos industriais declina. Com a padronização da produção nos setores líderes, as desvantagens estruturais que a periferia apresentava para a produção nos setores líderes começam a diminuir. Neste momento, os mercados da periferia ainda não foram muito explorados. $\mathrm{O}$ declínio nas taxas de lucro no centro e a lucratividade crescente do investimento industrial na periferia induzem fluxos de capitais para a periferia. Os capitalistas do centro relutam em reinvestir lucros na produção e, ao invés disso, depositam seu capital no sistema financeiro, gerando um excesso de liquidez que toma forma de investimento externo direto ou de empréstimos externos para a periferia (incluindo a compra de títulos da dívida pública de Estados da periferia).

Quarta Fase: Depois que a expansão do paradigma tecnológico específico daquele ciclo para a periferia foi completada e o potencial de inovação no paradigma vigente nas áreas do centro foi exaurido, a estagnação começa a prevalecer na economia-mundo. Os agentes empresariais buscam contê-la através de ganhos inflacionários passageiros e pela realização de fusões e aquisições (centralização do capital e formação de oligopólios). Alguns Estados passam a adotar práticas protecionistas e colonialistas. Durante este estágio, os países da periferia tornam-se progressivamente incapazes de arcar com o serviço de suas dívidas externas por várias razões. O declínio da demanda causado pela estagnação econômica no centro provoca a reversão das expectativas prévias e excessivamente otimistas sobre as receitas de exportação dos países periféricos tomadores de empréstimos. A queda das receitas de exportação efetivas, relativamente àquelas esperadas, força os países periféricos a tomarem mais empréstimos; assim, a concessão de créditos torna-se progressivamente especulativa, aumentando a fragilidade do sistema financeiro internacional.

Não só as piores condições de demanda nos mercados centrais prejudicam o retorno gerado pelos projetos de investimento na periferia e semiperiferia. A lucratividade do capital estrangeiro investido nestas regiões também pode ser menor do que o esperado, devido ao tamanho limitado de seus mercados, ao baixo efeito multiplicador do capital estrangeiro (especialmente em economias de enclave) ou ao alto coeficiente de importação e demanda de divisas estrangeiras dos projetos de investimento correspondentes.

Adicionalmente, como resultado das pressões de vários grupos sociais numa fase de estagnação, os governos dos Estados periféricos e semiperiféricos podem recorrer a uma alocação de recursos politicamente relevante, para fins de legitimação, mas financeiramente irracional (por exemplo, concessão de subsídios, manutenção de grandes redes de clientelismo), o que dificulta a geração de receitas para o pagamento da dívida externa. O uso dos recursos externos feito por parte dos Estados periféricos depende de seus regimes políticos, isto é, da base social sobre a qual os governos se sustentam e que legitima seu poder político. 
Em decorrência desses fatores, eventualmente, as dificuldades crescentes de serviço da dívida externa levam ao deflagramento de uma crise generalizada. Só agora, na medida em que aplicações lucrativas virtualmente desapareceram, os agentes empresariais do centro começam a investir em inovações básicas que não prometem altos lucros inicialmente. Finalmente, a introdução de inovações básicas irá viabilizar um novo ciclo longo. Neste sentido, o papel do sistema financeiro internacional é promover a expansão geográfica do ciclo, canalizando capital para os setores líderes e suas indústrias fornecedoras à medida que tais setores expandem no sistema-mundo de acordo com a progressão do ciclo de produto.

A seguir, apresentam-se a terceira e quarta fases do ciclo mundial de endividamento da última metade do século XIX. No início dos anos 1880, o mercado inglês de capitais dispunha de uma ampla massa de recursos financeiros e estava em busca de novas áreas de investimento, não sujeitas à severa concorrência a que os produtores e capitais do Reino Unido estavam sendo submetidos na Europa e em outros países (Rapoport, 2003). Como resultado, as taxas de juros haviam diminuído na Europa, estimulando a exportação de capitais. De acordo com Kindleberger (1985), a onda de exportação de capitais foi incitada por dois fatores domésticos: a conversão de títulos promovida pelo Visconde Goschen, ministro das finanças britânico, do ano de 1888, que reduziu as taxas de juros e fez investidores procurarem ativos mais rentáveis; e a antecipação de uma intensificação da severidade da lei de sociedades comerciais de 1862, que estimulou companhias privadas a abrirem o capital antes que isso se tornasse mais difícil.

Assim, após os anos difíceis da década de 1870, o fluxo de capital se intensificou para os países semiperiféricos mais viáveis economicamente: EUA, Argentina, Austrália e Rússia. O investimento na América do Sul saltou de 44,1 milhões de libras, entre 1873-82, para 182 milhões de libras, no período de 188391, grande parte do qual foi direcionado para a Argentina, então o país mais desenvolvido do subcontinente (Stewart, 1993).

Com isso, no fim dos anos 1880, ocorreu uma febre de empréstimos públicos concedidos a Estados periféricos e semiperiféricos. Os Estados sulamericanos e as colônias sul-africanas receberam vultosas somas de capital europeu. A Austrália recebeu capital inglês sob a forma de empréstimos públicos. Os empréstimos das três colônias - Vitória, Nova Gales do Sul e Tasmânia elevavam-se, ao fim dos anos 1880, a 112 milhões de libras esterlinas, dos quais 81 milhões foram investidos na construção de ferrovias.

Os empréstimos britânicos para a América Latina atingiram seu ápice em 1888 e 1889, mas, ao final da década de 1880, a exportação de capital pelas regiões centrais diminui. A Tabela 1 apresenta a evolução da exportação de capital 
pelos países centrais entre 1885 e 1893, ilustrando o movimento descrito nos parágrafos acima.

Tabela 1

Novos investimentos de portfólio, 1885-1893 (em milhões de libras)

\begin{tabular}{l|c|c}
\hline Ano & Mercado mundial de capitais & Investimentos britânicos \\
\hline 1885 & 124,7 & 52,7 \\
\hline 1886 & 251,7 & 74,4 \\
\hline 1887 & 190,0 & 83,7 \\
\hline 1888 & 295,9 & 133,3 \\
\hline 1889 & 501,9 & 138,5 \\
\hline 1890 & 223,9 & 110,7 \\
\hline 1891 & 225,5 & 51,8 \\
\hline 1892 & 93,5 & 40,1 \\
\hline 1893 & 134,7 & 31,5 \\
\hline
\end{tabular}

(a) Extraído por Kindleberger (1985) da publicação belga "Le moniteurs des intérêts matériels", é de utilidade limitada pois inclui apenas investimentos em ferrovias e títulos industriais, e tanto emissões domésticas quanto no estrangeiro.

Fonte: Extraído de M. Simon (1967/1978) por Kindleberger (1985, p. 229).

Devido à contração brusca no influxo de capital externo, o pesado serviço da dívida externa dos Estados periféricos e semiperiféricos, contraída nos anos anteriores, recaiu sobre as exportações. Estas, porém, atravessavam uma fase ruim. Canadá, Argentina e Austrália (que haviam recebido grandes somas de capital britânico) tinham se especializado na produção de trigo para a Europa e, na década de 1880 , ocorreu um declínio de aproximadamente $45 \%$ no preço do trigo, que persistiu até o fim do século, acompanhando a Grande Depressão e dificultando o pagamento do serviço de sua dívida externa. Uma vez que o balanço de pagamento desses países passou a apresentar problemas, o fluxo de capital para estas áreas se reduziu ainda mais. Quando as taxas de juros britânicas se elevaram, a situação mostrou-se insustentável. Entre 1890 e 1893, crises econômicas envolveram Inglaterra, Argentina, Transvaal, México, Uruguai e Austrália (Luxemburgo, 1984). Em 1891, a Argentina entrou em "default", sendo seguida pela Austrália, Portugal e Grécia em 1893 (Stewart, 1993) e pelo Brasil em 1898. Kindleberger (1985) ainda acrescenta a esta lista: a crise parisiense-panamenha iniciada em 1888 e finalizada em escândalo em 1893, além do colapso do "Comptoir d'Escompte" em 1889; o colapso de uma série de bancos italianos entre $1887 \mathrm{e}$ 1893; e o pânico do ouro em Nova York entre julho e outubro de 1893.

\section{Segundo Kindleberger (1985),}

[O] mecanismo de propagação do boom e das crises foram principalmente os movimentos de capital e preços, incluindo preços de comodites e ativos financeiros [...] o centro da crise mundial estava em Londres, que financiara o "boom". A 
interrupção das exportações de capital trouxe a crise. As crises no resto do mundo estavam conectadas a Londres especialmente através da criação de companhias em Londres para investimento em diamantes e ouro na África do Sul, bancos que operavam especialmente na África do Sul, Austrália e América Latina, ferrovias nesses continentes e nos EUA, companhias de hipoteca na Argentina e na Austrália, companhias de nitrato no Chile e similares (p. 227).

\section{Evolução da economia na Argentina (1877-1890)}

No último quartel do século XIX, a economia na Argentina era predominantemente primário-exportadora, com destaque à produção de lã, carnes e cereais. Estas atividades agrícolas e suas atividades acessórias (construção de infraestrutura, comércio internacional, etc.), ao mobilizarem os enormes recursos potenciais da pampa úmida, proporcionavam uma alta taxa de rentabilidade. Investidores estrangeiros, num contexto de liquidez excessiva, aplicaram maciçamente capital na Argentina, obtendo picos de rentabilidade de 10 a $15 \%$ de dividendos anuais, que não se obtinham facilmente em outras partes do mundo (Rapoport, 2003).

A onda de exportação de capital pelos países centrais dos anos 1880 também invadiu a Argentina e destinou-se principalmente ao setor público e obras de infraestrutura. Como tais obras requeriam insumos estrangeiros, as importações aumentaram em volume e mudaram de composição. As importações aumentaram de 45 milhões de pesos ouro, em 1880, para 142 milhões, em 1890. No mesmo período, as importações per capita duplicaram (Rapoport, 2003). A participação de bens de capital e de matérias-primas nas importações cresceu, em decorrência da inversão estrangeira realizada naqueles anos. Aquelas, então, consistiam principalmente em material ferroviário, bem como para a construção de obras públicas portuárias, sanitárias, construção de habitações, desenvolvimento urbano, etc.; e havia também insumos, ferro, aço, combustível, etc., que tinham idêntica finalidade: a formação da infraestrutura básica da economia agroexportadora (Rapoport, 2003). Como o "boom” das exportações agropecuárias só começaria na década de 1890, entre 1882 e 1890 a balança comercial foi permanentemente deficitária e financiada pelo influxo de capital estrangeiro.

Já entre 1880 e 1890, a ação do Estado foi intensa, definida para facilitar a integração da Argentina aos mercados mundiais. Reformas monetárias e cambiais subsequentes ao programa de estabilização promovido pelo presidente Avellaneda, em reação a uma crise econômica ocorrida na década de 1870 , tornavam a economia local mais atrativa aos investimentos estrangeiros. Até 1883, quando foi criada a moeda nacional - o peso - havia um verdadeiro caos monetário na Argentina, em que cada província tinha sua própria moeda. Em 1884/85, ocorreu a adoção da conversibilidade da moeda, com padrão bimetalista, e o estabelecimento, em 1885, de dois sistemas monetários - o de papel-moeda 
nacional para uso doméstico, e o de ouro e libra para as trocas internacionais. Estas reformas monetárias, somadas às anteriores políticas ortodoxas de Avellaneda, ao proporcionarem um retorno mais seguro ao capital estrangeiro investido no país, atraíram o capital circulante mundial e permitiram um aumento considerável da dívida externa estatal.

Ainda em matéria monetária, o Estado aceitou e estimulou a depreciação cambial em benefício dos exportadores. De modo geral, as elites exportadoras, em anos economicamente favoráveis, pressionavam pela adoção do padrão-ouro, a fim de evitar a apreciação da moeda doméstica. Em anos desfavoráveis, pressionavam pela depreciação do peso. Adicionalmente, pelo menos até 1890, o Estado manejou o crédito com grande liberalidade através dos bancos estatais (como será visto a seguir).

O Estado fomentou as inversões estrangeiras com amplas garantias, assumindo o risco das menos atrativas, para logo transferi-las aos empresários privados quando o êxito estava assegurado. Sobretudo, realizou a "Conquista do Deserto", de que resultou a incorporação de vastas extensões de terra, tomadas dos índios, aptas à exploração, e que foram transferidas em grandes extensões e a um custo mínimo a particulares poderosos e bem relacionados (Romero, 2001).

Com recursos crescentes, gerados por um cenário favorável de expansão do comércio mundial (que aumentava as receitas tributárias aduaneiras) e disponibilidade de crédito (típico das terceiras fases dos ciclos mundiais de endividamento), o governo pôde encarar obras que vinham sendo até então proteladas, como a construção dos portos de Buenos Aires. Em 1890, o governo da Argentina gastava o equivalente a $12 \%$ até $14 \%$ de seu PIB. ${ }^{9}$ Ao longo da segunda metade do século XIX, o gasto público cresceu muito, em consequência do aumento tanto das exportações quanto das importações, que eram a principal fonte de receita (Fausto; Devoto, 2004), e do acesso ao endividamento externo.

Os novos créditos contraídos no exterior foram destinados ao Banco Nacional, às estradas de ferro (uma das indústrias líderes do paradigma tecnoeconômico vigente) e às obras do porto de Riachuelo. Em 1884/85, também ocorreram emissões de títulos da dívida externa para financiar ferrovias e obras de salubridade. De 1885 a 1890, a maior parte da dívida externa contraída foi relativa a empréstimos públicos, estradas de ferro e hipotecas sobre terras. Na década de 1880, ao contrário da década de 1870, o serviço da dívida externa tinha de ser pago imediatamente após a contração do empréstimo (Lenz, 2004), fazendo com

(9) Estes números estavam no mesmo patamar de alguns países europeus, como a Itália (10\%), mas eram muito superiores aos dos EUA, onde, no contexto de um Estado plenamente federal, o gasto nacional chegava a escassos 3\% do PIB. 
que o aumento da dívida externa comprometesse de imediato as contas públicas e o balanço de pagamentos.

Porém, se num primeiro momento o endividamento externo permitiu ao Estado aumentar o gasto público, num momento posterior a dependência financeira passou a comprometer sua ação. Entre 1881 e 1886, em média, a razão entre o resultado primário das contas públicas e o montante necessário para o serviço da dívida foi de $-300 \%^{10}$ (Bózzoli; Della Paolera; Irigoin, 2003). Os encargos da dívida não eram tão altos quando comparados ao saldo da balança comercial e, sobretudo, aos níveis que atingiriam no futuro; porém, sua persistência e tendência ao crescimento, que redundavam numa balança de pagamentos cronicamente negativa, significavam uma pesada carga para as finanças estatais e, portanto, um empecilho para a execução das políticas públicas (Fausto; Devoto, 2004), demonstrando o alto condicionamento que gerava sobre a ação do Estado argentino.

Em meados da década de 1880, os acionistas britânicos das companhias ferroviárias começam a exigir maiores dividendos. Em 1884, os gastos do governo superavam em 56\% as receitas, o que gerava um enorme déficit fiscal (Regalsky, 1998 apud Rapoport, 2003). Ao fim do mesmo ano, o setor externo entrou em crise, num cenário de redução do crescimento econômico mundial, e o influxo de capital estrangeiro se deteve devido à perda de confiança que se produziu no exterior como consequência do maior déficit da balança comercial e do sensível aumento dos pagamentos de juros e rendimentos dos empréstimos, cujo cumprimento começava a se pôr em dúvida (Rapoport, 2003).

O governo do general Roca tomou medidas para restaurar a confiança e induzir investidores a comprar títulos argentinos e ações das companhias ferroviárias. Carlos Pellegrini, ministro de Estado, firmou acordo com banqueiros europeus para hipotecar rendas aduaneiras argentinas e proibir a contração de novos empréstimos sem seu prévio consentimento (Lenz, 2004), medidas que caracterizam a subordinação aos interesses das altas-finanças. $\mathrm{O}$ acordo garantiu o re-estabelecimento da confiança dos investidores estrangeiros, mas a conversibilidade teve de ser suspensa em outubro de 1885, ante a carência de ouro - e não voltaria a ser estabelecida por mais de uma década, tendo, portanto, vigorado por um curto período (1884/85). A manutenção da conversibilidade dependia de diversos fatores que estiveram longe de se concretizar. Um país cuja economia estava tão dependente do comércio exterior e que não era produtor de ouro só podia ter uma moeda conversível com uma balança de pagamentos

(10) Conforme os autores, quanto menor este valor, pior a capacidade de pagamento e o crédito do Estado. 
permanentemente favorável, o que não era o caso naquele momento (Rapoport, 2003).

A suspensão da conversibilidade ensejou a expansão monetária desenfreada. Entre 1885 e 1890, o crescimento do meio circulante implicou a elevada taxa anual de 30\%, e um dos motivos para isso foi a Lei de Garantia Bancária, instituída por Juarez Celman, eleito presidente em 1887 (Lenz, 2004). Sua política econômica foi expansionista, com inversões financiadas externamente e mediante política interna creditícia e bancária desregrada. A ele interessava mais a continuidade e o êxito do programa de investimentos estrangeiros do que a estabilidade monetária ou cambial (Rapoport, 2003).

Como ficou dito, em 1887 foi instituída a Lei de Garantia Bancária, segundo a qual qualquer banco poderia emitir cédulas, desde que mantivesse certos depósitos em ouro no Tesouro Nacional. Com esta lei, os governos provinciais que queriam monetizar seus déficits fundaram bancos. Precisavam, para isso, manter depósitos em ouro no Tesouro Nacional para obter em troca bônus nacionais que lastreassem suas emissões. Este ouro foi emprestado do exterior e a contrapartida destes empréstimos era dada pelos próprios bônus nacionais. Assim, numa complexa relação, a dívida interna nacional era o anverso das dívidas externas provinciais.

Entre 1886 e 1890, a Argentina tomou emprestado quase 700 milhões de pesos-ouro. Ademais, o crédito bancário se incrementou espetacularmente, multiplicando-se doze vezes entre 1881 e 1889. À emissão excessiva e à especulação de todo tipo se associava um consumo suntuoso que agravava a situação. O presidente chegou a privatizar ativos estatais, como as ferrovias Andina e Central Norte, para obter recursos e manter o elevado gasto público (Regalsky, 1999 apud Rapoport, 2003). Como era de se esperar, o crescimento da dívida pública externa entre 1885 e 1889 foi notável (Tornquist, 1920 apud Rapoport, 2003).

O descontrole monetário e financeiro estava, assim, lastreado no endividamento externo (Rapoport, 2003). Após dois anos da promulgação da lei, o ouro recebido pelo governo nacional passou a ser aplicado na amortização da dívida externa. Porém, os bancos garantidos não realizavam integralmente os depósitos em ouro que deveriam junto ao Tesouro Nacional (Lenz, 2004).

Os bancos garantidos utilizaram a faculdade concedida pelo Estado para emitir cédulas bancárias e responderam à crescente demanda por crédito do público, o que resultou numa enorme expansão monetária e abuso do crédito público como forma de viabilizar financeiramente a ação tanto para o governo nacional como para os governos provinciais, reforçando comportamentos clientelistas (Lenz, 2004). 
Destarte, uma das razões para o aumento da emissão monetária foi o elevado incremento do gasto público, que sustentou, em boa parte, a expansão econômica do período. A expansão do gasto estatal não era somente o resultado de uma previsão otimista de crescimento da arrecadação, mas também das possibilidades que oferecia o endividamento externo (Rapoport, 2003).

Em torno do Estado se conformou um importante setor de especuladores, intermediários e financistas, que participou de concessões, empréstimos, obras públicas, compras ou vendas, especialmente na década de 1880, quando o Estado injetou maciçamente crédito através dos bancos garantidos (Romero, 2001). Esta é uma manifestação concreta de um dos fatores responsáveis pelas crises de endividamento externo da periferia, segundo a teoria dos ciclos mundiais de endividamento, isto é, a aplicação ineficiente dos recursos viabilizados pelo endividamento externo em projetos que, embora não fossem viáveis economicamente, atendiam a conveniências políticas, tal como a concessão de benefícios a grupos privilegiados com o fim de garantir apoio político (e assim viabilizar e sustentar o próprio Estado).

Estas circunstâncias fizeram que, em abril de 1890, o prêmio do ouro chegasse a 209\%, enquanto que, apesar do incremento do meio circulante, existia, segundo Williams (1921), uma grande falta de liquidez. As exportações não lograram expandir-se na medida suficiente para fazer frente aos serviços da dívida e a crise deveria estourar, inevitavelmente, quando o fluxo de empréstimos do exterior se interrompesse. Isto ocorreu quando a desconfiança sobre a situação argentina começou a se disseminar no exterior e a casa Baring Brothers, agente do governo argentino, só pode continuar vendendo em Londres os títulos do país com grandes perdas (Rapoport, 2003).

Assim, se a maioria dos empréstimos e investimentos estrangeiros contribuiu, com certas limitações, para o arranque econômico do país, os serviços da dívida externa se transformaram em uma pesada carga que só pôde ser compensada temporariamente, quando a balança comercial começou a ter fortes superávits a partir de 1891. Segundo Cortes Conde (1997), o endividamento externo aumentou notavelmente nas décadas de 1880 e 1890. A dívida externa total, que em 1880 era de 33 milhões de pesos-ouro, em fins do decênio chegava a 300 milhões, isto é, havia aumentado quase dez vezes (Rapoport, 2003). Em virtude disso, o serviço da dívida externa, que permanecera em torno de $10 \%$ do orçamento federal entre 1850 e 1880 (com uma queda no início da década de 1860), na década de 1880 chegaria a $18 \%,{ }^{11}$ a despeito do crescimento das receitas fiscais. (Fausto; Devoto, 2004). público.

(11) Com o serviço total da dívida interna e externa estabilizando-se no patamar de $30 \%$ do orçamento 
Felipe Amin Filomeno

A dívida pública da Argentina quase quadruplicou entre 1880 e 1890, com a novidade de que também as províncias começaram a contrair empréstimos no exterior. Por isso, nesse período houve uma forte tendência a gerar déficits orçamentários, bem exemplificada pelos dados de 1889 . Neste ano, às vésperas da crise Baring, o serviço da dívida pública equivalia a $20 \%$ do orçamento do Estado e a $31 \%$ da receita tributária, apesar da grande expansão da economia que ampliara os recursos fiscais ao longo da década (Fausto; Devoto, 2004).

Ademais, embora neste período os empréstimos públicos nacionais, municipais e provinciais, realizados mediante a colocação de títulos nos mercados financeiros internacionais, tenham sido numerosos, bens vendidos e cotados, nos momentos de crise - como na breve recessão de 1885 ou na mais profunda de 1890 - a confiança dos investidores pareceu dissipar-se muito rapidamente, revelando a fragilidade com que o Estado controlou o processo de endividamento externo (Rapoport, 2003). Isso caracterizou, também, a perda de autonomia do Estado num quadro de alta mobilidade internacional de capital, típica das expansões financeiras, que permite aos investidores externos muita influência na determinação da dinâmica econômica local, além do que o Estado era capaz de controlar.

\subsection{A crise Baring}

O clima de desordem monetária, a febre especulativa e o alto endividamento externo do fim dos anos 1880 compuseram o cenário para uma crise de grandes proporções na Argentina, no início do decênio de 1890. Um dos personagens centrais deste evento foi a casa bancária britânica Baring Brothers que, atraída por políticas governamentais favoráveis ao investimento estrangeiro, canalizou para a República Argentina vastas somas e garantiu seus rendimentos. De fato, o Banco Baring foi a mais importante instituição financeira estrangeira presente na Argentina no século XIX. Até 1880, foi o principal agente financeiro do governo da província de Buenos Aires e, depois, do governo nacional. O banco foi responsabilizado pela febre especulativa dos anos 1880 e pelas condutas irresponsáveis (relativas à expansão da dívida externa e da oferta monetária) que culminaram na crise de 1890, a qual ficou, ipso facto, conhecida como "crise Baring" e interrompeu, por uma década, o desenvolvimento da economia exportadora.

Embora políticos e financistas contemporâneos tenham atribuído a crise à febre especulativa local, as causas eram mais profundas e se mostraram recorrentes. A estreita vinculação das atividades econômicas locais com a economia-mundo tornava o país sensível a flutuações cíclicas, como havia ocorrido em 1873. O forte endividamento convertia o serviço da dívida externa em uma carga onerosa, solucionada com novos empréstimos ou com os saldos do 
comércio exterior, e ambas as coisas se reduziam drasticamente nos momentos de crise cíclica, gerando um período mais ou menos prolongado de recessão (Romero, 2001).

O intenso endividamento externo - que, nos anos 1880, propiciara o aumento do meio circulante -, a desordem monetária e a consequente febre especulativa, na década de 1890 , cresceram a ponto de comprometer a capacidade da República Argentina de honrar seus compromissos externos. A dívida pública externa, que em 1874 correspondia a 10 milhões de libras, na década de 1890 chega a 59 milhões de libras (Lenz, 2004). Calculando-se juros anuais de $6 \%$ e amortizações de $1 \%$, a saída de capital decorrente do endividamento externo chegava a aproximadamente 60 milhões de pesos-ouro. Somem-se a isto os montantes comprometidos com as remessas de lucros que as empresas estrangeiras enviavam às matrizes, os $7 \%$ de garantia sobre o capital investido em ferrovias (que o governo havia se comprometido em pagar as companhias ferroviárias), as remessas de imigrantes e as divisas gastas no exterior por turistas argentinos. Finalmente, deve-se ter em conta o saldo negativo do comércio exterior que, em 1890, chegou a 41 milhões de pesos-ouro (Rapoport, 2003). Ao final da década de 1890, devido à prosperidade de anos anteriores e à abundância de empréstimos externos, a dívida externa do Estado nacional argentino havia chegado a 300 milhões de pesos-ouro (Lenz, 2004).

Enquanto os fundos do exterior foram afluentes, não houve problemas no balanço de pagamentos. O país obtinha com eles as divisas necessárias para fazer frente ao pagamento do serviço da dívida externa e à manutenção do nível de consumo de produtos importados. Todavia, o alto nível de endividamento, a especulação e a desordem monetária presentes na Argentina fizeram desaparecer a confiança dos investidores estrangeiros na capacidade de pagamento do governo argentino. Quando as taxas de juros britânicas se elevaram, a situação mostrou-se insustentável. Já em 1889, o influxo de capitais estrangeiros caiu abruptamente, concomitante à queda dos preços mundiais dos produtos argentinos. Em junho de 1890, ocorreu a suspensão dos pagamentos dos dividendos trimestrais pelo governo argentino, que subscreveu novo empréstimo com o Banco Baring para evitar novos impostos e a alta do ouro. Em novembro do mesmo ano, Londres não permitiu o adiamento do pagamento da dívida externa argentina, nem a continuação da transferência trimestral de fundos para o país (Lenz, 2004).

Os projetos de infraestrutura financiados pelos empréstimos externos, como as ferrovias e os melhoramentos de terras, tiveram impactos positivos sobre as exportações apenas após certo período de maturação, tendo sido inicialmente onerosos para o balanço de pagamentos. Só por volta de 1893, após a crise Baring, tais projetos alcançaram maturidade e as exportações aumentaram; porém, ainda não a ponto de compensar a queda de preços destas. 
Felipe Amin Filomeno

Em conformidade com a teoria dos ciclos de endividamento externo, os hiatos temporais entre a decisão de investimento e a realização dos lucros esperados dos grandes projetos de infraestrutura geraram dificuldades para honrar o serviço da dívida, pois este aumentava enquanto a produção resultante dos investimentos ainda era baixa. Quando tal fato foi percebido pelos investidores estrangeiros, eles pararam de conceder empréstimos, tendo como resultado uma crise de endividamento externo. Assim, o governo argentino não conseguiu cumprir suas obrigações externas, desencadeando uma séria crise financeira.

Quando o governo argentino decidiu que não arcaria com suas obrigações externas, a casa Baring, logo depois de intimar o governo para que arcasse com seus vencimentos para evitar a liquidação, teve de fechar provisoriamente suas portas, devido ao alto comprometimento de suas aplicações em títulos argentinos sendo salva, em última instância, pelo governo britânico. Durante a crise, o governo britânico se recusou a intervir diretamente a favor dos investidores ingleses (Lenz, 2004).

$\mathrm{Na}$ Argentina, alguns dos principais bancos se declararam em bancarrota e, uma vez fracassados os intentos para ajudá-los, entraram em liquidação. Finalmente, outorgou-se uma moratória geral, enquanto a cotação dos títulos e ações dos bancos e empresas mais importantes declinava de forma espetacular. A crise levou à quase paralisação da atividade econômica e à renúncia do presidente Juárez Celman. Em seu lugar, em agosto de 1890, assume Carlos Pellegrini, com o objetivo de solucionar a crise financeira e a inadimplência dos débitos externos. Nos anos 1890, o governo nacional implementou uma política monetária ortodoxa, que acarretou deflação. Pellegrini determinou a paralisação das obras públicas, a demissão de empregados supérfluos e, em 1891, afirmou a necessidade de reformular o sistema financeiro para evitar o descontrole monetário e considerou necessária a privatização de bancos oficiais (Lenz, 2004).

A postura de Pellegrini agradava aos banqueiros europeus. Em novembro de 1890, com a possibilidade de bancarrota do próprio Banco Baring, o governo inglês nomeia uma comissão internacional de credores presidida por Lord Rothschild. Em março de 1891, o representante argentino Victorio de la Plaza e a comissão Rothschild firmam um acordo (conhecido como "Acordo Rothschild") pelo qual o Tesouro Britânico e o Banco da Inglaterra emprestariam 17 milhões de libras à Argentina. Pelo acordo, o Banco da Inglaterra continuaria a aceitar os papéis do Banco Baring. Por seu lado, banqueiros alemães e franceses ficam insatisfeitos com a proposta e não tomam parte do acordo. Politicamente, o Acordo Rothschild foi considerado muito liberal e, por isso, conseguiu manter o valor dos títulos argentinos. Direitos de aduana da Argentina também foram dados como garantia. Deste acordo, ficaram excluídas as dívidas provinciais, municipais 
e as cédulas hipotecárias. No fim das contas, o acordo resultou em aumento no endividamento externo (Lenz, 2004).

Ainda em meados de 1891, várias ações se efetivam: é implementada uma reforma tributária, realizado um ajuste draconiano no sistema bancário e estabelecido um órgão independente para controlar a base monetária (o Banco de la Nación), além de renegociada a dívida externa (Della Paolera, 1994 apud Lenz, 2004). A partir de então, os bancos já não se dedicariam à emissão, ficando o papel-moeda do governo nacional como único instrumento oficial (Lenz, 2004).

Em 1892, Sáenz Peña é eleito presidente e nomeia Romero ministro da Fazenda, fato que agradou os credores internacionais, pois se tratava de alguém com postura contrária a inflação descontrolada, créditos fáceis e que defendia a estabilização da moeda e a retomada dos investimentos externos. Em 1893, firmase o Acordo Romero, envolvendo redução de juros em torno de $4 \%$ pelos cinco anos seguintes e suspensão de amortizações até janeiro de 1901. Os pagamentos de juros ficariam reduzidos em torno de $30 \%$. O país pagaria seus débitos com recursos correntes e não com novos empréstimos (Lenz, 2004). Em 1896, através do Acordo Terry, as dívidas externas provinciais são incorporadas às do governo nacional. Logo após os Acordos Rothschild e Romero, a razão dívida externa/exportações era de, respectivamente, 2,23 e 2,45 (Lenz, 2004).

A crise de endividamento externo abrira as portas para a implementação de políticas econômicas ortodoxas, consubstanciando seu condicionamento direto pelas altas-finanças internacionais. As medidas econômicas foram voltadas, então, à estabilidade monetária e ao equilíbrio orçamentário necessários para a geração das divisas que seriam usadas para o pagamento dos compromissos externos. $\mathrm{O}$ Estado nacional se submeteu à disciplina imposta pelos seus credores, propondose a conter gastos, controlar a oferta de moeda e garantir o serviço da dívida com as receitas de aduana.

Conforme afirmado anteriormente, a crise levara o governo a desvalorizar inicialmente a moeda, gerando uma queda do peso de até $400 \%$ que estimulou as exportações e inibiu as importações. Mas as políticas monetárias contracionistas implementadas para solucionar a crise tiveram como consequência uma apreciação do peso, que passou a preocupar a classe dos exportadores, os quais passam a pressionar pela contensão da valorização da moeda doméstica através da adoção da convertibilidade. Em 1899, foi então criada a "caja de conversión", implicando o retorno ao padrão-ouro que havia sido abandonado em 1885, e que passou a vigorar até 1914. As faculdades de emissão foram definitivamente desligadas dos bancos e transferidas para um organismo "ad hoc", a "caja de conversión" (Regalsky, 1999 apud Lenz, 2004). Para Jones (1992 apud Lenz, 2004), tais medidas resultaram num sistema monetário ultraconservador. 
A crise Baring de 1890 marcou um ponto de inflexão no investimento estrangeiro, que se reduziu consideravelmente até fins do século XIX. Isto, somado à forte carga da dívida externa, originou um grande saldo negativo na balança de capitais. Contudo, neste momento começou a produzir-se o boom das exportações agropecuárias, o que permitiu equilibrar o balanço de pagamentos (Rapoport, 2003). Com a melhora nos termos de intercâmbio, foi recobrada a confiança e a estabilidade na Argentina. $\mathrm{O}$ volume do comércio internacional aumentou muito e, em 1897, o balanço de pagamentos foi tão favorável que dívidas foram pagas antes do prazo previsto (Lenz, 2004). As condições do mercado mundial criaram uma demanda externa por produtos argentinos que rapidamente reviveu o crescimento liderado por exportações (Rock, 2002), em conformidade à teoria dos ciclos mundiais de endividamento.

A Tabela 2 sumariza a evolução de indicadores econômicos importantes do período.

Tabela 2

Sumário da evolução de indicadores econômicos da Argentina

\begin{tabular}{c|c|c|c|c|c|c}
\hline & Inflação & $\begin{array}{c}\text { Desvalo } \\
\text {-rização } \\
\text { cambial } \\
(\%)\end{array}$ & $\begin{array}{c}\text { Cresci- } \\
\text { mento } \\
\text { econômico } \\
(\%)\end{array}$ & $\begin{array}{c}\text { Resultado } \\
\text { primário do } \\
\text { governo/ } \\
\text { serviço da } \\
\text { dívida pública } \\
(\%)\end{array}$ & $\begin{array}{c}\text { Razão dívida } \\
\text { pública/ } \\
\text { exportações } \\
(\%)\end{array}$ & $\begin{array}{c}\text { Razão dívida } \\
\text { pública/ } \\
\text { PIB (\%) }\end{array}$ \\
\hline $1881 / 86$ & $-2,0$ & 4,2 & 8,1 & -300 & 181 & 58,3 \\
\hline $1887 / 90$ & 14,1 & 17,9 & 5,4 & -419 & 281,4 & 82 \\
\hline $1891 / 92$ & 17,8 & 16,5 & 4,4 & 15 & 366,9 & 124,7 \\
\hline $1893 / 94$ & $-4,2$ & 4,5 & 2,9 & 840 & 420,7 & 113,8 \\
\hline
\end{tabular}

Fonte: Bózzoli; Della Paolera; Irigoin (2003,p. 46-76).

\section{A evolução da economia no Brasil (1877-1898)}

A onda de exportação de capital dos países centrais afetou também o Brasil. Na última década imperial, o endividamento externo sofreu constantes acréscimos, em virtude de se ter constituído em importante alternativa para o financiamento do déficit público brasileiro. Quatro operações de empréstimo externo foram realizadas entre 1883/1889, a saber: 1883 (£4.599.600) destinado às garantias de juros das companhias estabelecidas, obras para abastecimento de água e conversão da dívida flutuante consolidada; 1886 (£6.431.000) para consolidar dívida flutuante e restabelecer o equilíbrio financeiro; 1888 (£6.297.300) para auxílios à lavoura; 1889 (£19.837.000) para conversão dos débitos de 1865, 1871, 1875, 1886 (Orair, 2002). De acordo com Kindleberger (1985, p. 228), em 1888 o governo brasileiro aproveitara-se da conversão Goschen em Londres para converter seus empréstimos de 1865, 1871 e 1876 (que pagavam 5\% de juros) em 
títulos que pagassem $4 \%$ de juros e $0,5 \%$ de amortização. O valor total dessas operações contraídas entre 1883 e 1889 (37,2 milhões de libras) supera o total dos empréstimos realizados nos 59 anos anteriores (32,5 milhões de libras). A dívida externa dobrou, passando de 15 milhões em 1882, para 30,3 milhões de libras em 1889 (Orair, 2002).

A política monetária imperial, sempre na mira da conversibilidade da moeda, teve de pautar-se no crescente endividamento externo e na manutenção da escassez de meio circulante (Tannuri, 1981). A política monetária adequava o volume de moeda às reduzidas necessidades monetárias de atividades econômicas baseadas em trabalho escravo, a despeito do desenvolvimento do comércio e da entrada de imigrantes antes de 1888 . Nesse período, registrou-se simultaneamente o crescimento do valor do comércio exportador e a diminuição da quantidade de papel-moeda (Saes, 1985, p. 154). Entre 1880 e 1889, a quantidade de papelmoeda em circulação diminuiu de 216 para 197 mil contos, enquanto o valor do comércio exterior (exportações mais importações) cresceu de 411 para 477 mil contos (Furtado, 1998, p. 170).

Especialmente a partir de 1886, a economia cafeeira iniciara um novo ciclo, caracterizado, em seus primeiros anos, pelo grande ascenso de preços. A procura no mercado externo crescia, ao mesmo tempo em que a oferta seguia um ritmo irregular, devido às condições próprias do cultivo do café. Graças à oscilação da oferta e à expansão da procura, os preços mundiais do café duplicaram entre 1885-1890 (Fausto, 1989). No final da década de 1880, uma praga assolou os concorrentes asiáticos do Brasil, favorecendo a produção local (Dean, 2002). Entretanto, do ponto de vista da renda da cafeicultura, a elevação da taxa cambial, a partir de 1887, provocada em parte pela própria ascensão do preço mundial do produto, limitava o alcance da alta e o estímulo para novas plantações (Fausto, 1989).

Na década de 1880, o Brasil passa a gozar de um virtual monopólio na etapa de produção primária da cadeia mercantil mundial do café. Graças à atividade cafeeira, as finanças públicas, apesar dos déficits constantes, podiam fazer face às mais prementes necessidades administrativas e realizar algumas obras de vulto; e até a moeda, sempre tão precária, gozou de certa estabilidade nos últimos anos do governo imperial. Por sua vez, o crédito brasileiro no exterior era sólido, o que assegurava inversões crescentes de capitais estrangeiros, sobretudo empréstimos públicos. Este fluxo constante de capitais vindos de fora garantia o equilíbrio do balanço de pagamentos e das finanças públicas que, sem ele, mesmo com todos os progressos do país, não teria podido se manter. No mesmo ano em que a República foi proclamada, o governo imperial levantou em Londres seu último e mais vultoso empréstimo, no valor de quase 20 milhões de libras, destinado a converter diferentes créditos anteriores e pagar juros e amortizações 
vencidos. Isto já se tornara um recurso normal: quando não se podia pagar uma dívida vencida, ela se saldava com um novo empréstimo (Prado Jr., 1976).

$\mathrm{O}$ aumento do preço do café no mercado mundial significava para o Estado a possibilidade de desafogar os orçamentos federais. $\mathrm{O}$ incremento do valor das exportações permitia ampliar as importações - principal fonte de receita tributária da União. Além disso, a melhora nos termos de intercâmbio favorecia a valorização da moeda brasileira, possibilitando atender de forma um pouco menos onerosa os compromissos da dívida externa que deviam ser pagos em moeda estrangeira. Para os produtores, não convinha que o aumento dos preços internacionais se traduzisse em uma valorização cambial. É certo que, neste caso, poderiam adquirir bens importados em melhores condições. Mas, no que diz respeito a suas despesas internas, cujo significado era maior, o ascenso do câmbio poderia reduzir ou anular a alta das cotações. Daí as reivindicações dos cafeicultores no sentido de estabilizar o câmbio e impedir sua elevação quando os preços mundiais do café subiam, e de forçar a baixa quando estes declinavam (Fausto, 1989; Furtado, 1998) - tal como a elite agroexportadora argentina fazia.

A abolição da escravatura no Brasil (1888) criou condições para outros desenvolvimentos. O mercado, pelo menos no Sul e no Sudeste, expandiu-se enormemente com a chegada dos agricultores imigrantes. À medida que a renda monetária passou a ter maior importância, em conjunto com o desenvolvimento do Centro-Sul, a libertação dos escravos e a introdução de imigrantes, a política monetária imperial se revelou cada vez mais inadequada às necessidades do país. O Parlamento imperial chegou a aprovar, em 1888, uma reforma bancária e de fornecimento de crédito à agricultura, que começou a ser implantada com muitas vacilações (Fausto, 1989).

Nos últimos meses do Império, com a abolição da escravatura, foram lançados títulos do governo para ajudar os fazendeiros que, por conta da abolição, tinham sofrido a perda de seus escravos sem qualquer compensação. Esses fundos foram destinados diretamente aos seus credores da cidade, desencadeando um repentino surto de prosperidade (Dean, 2002). A necessidade de contentar a classe dos antigos proprietários de escravos estimulou o governo imperial a realizar novas emissões monetárias, que se destinaram em grande parte a auxiliar, através de créditos, a lavoura prejudicada pela libertação dos escravos (Prado Jr., 1976). No final da década de 1880, após a abolição, grandes empréstimos externos serviram de base a créditos para a agricultura enfrentar o momento de transição (Levy; Saes, 2001).

A abolição da escravidão tornou ainda mais difícil a adoção do padrãoouro pelo Brasil. A difusão do trabalho assalariado aumentava o efeito multiplicador da economia local relativamente ao que se observava quando ainda 
predominava o trabalho escravo. Devido ao efeito multiplicador, a procura monetária tendia a crescer mais do que as exportações, agravando a propensão ao desequilíbrio externo na economia brasileira (Furtado, 1998).

Com o advento da República, em 1889, a hegemonia da burguesia do café se estende do nível estadual ao nível nacional. Na Constituição de 1891, os grandes Estados federados impuseram os princípios que assegurariam esta hegemonia. Foi estabelecida ampla autonomia estadual, com a possibilidade de os Estados contraírem empréstimos externos e contarem com forças militares próprias. Na distribuição de rendas, atribuiu-se os impostos de exportação aos Estados-membros, garantindo assim a receita das unidades maiores e, em especial, a de São Paulo (Fausto, 1989). Os empréstimos externos estaduais e municipais que, em 1895, correspondiam a cerca de $8 \%$ da dívida pública externa total, em 1905 já correspondiam a 21\% (Abreu, 1985).

O governo provisório subsequente à Proclamação da República transformou as questões econômicas em sua principal preocupação e promoveu agressivamente o crescimento da economia. Os aspirantes a capitalistas e a industriais, junto com certos profissionais liberais urbanos e oficiais do exército politicamente ativos, indignados com a incompetência demonstrada na Guerra do Paraguai e com os escassos orçamentos militares depois da guerra, preconizaram um programa econômico intervencionista (Dean, 2002).

Nos anos iniciais da Primeira República, o Brasil foi perdendo participação (principalmente para a Argentina) nos fluxos de capitais britânicos destinados à América Latina, só vindo a recuperar o terreno perdido às vésperas da Primeira Guerra Mundial. As perdas, praticamente irreversíveis, ocorreram principalmente no campo dos investimentos diretos em empresas de propriedade majoritariamente britânica. $\mathrm{O}$ mesmo já não se deu com relação às aplicações do tipo "portfólio", que englobam tanto os empréstimos a governos (federal, estaduais e municipais), como a participação acionária minoritária de capitais britânicos em empresas privadas de outras nacionalidades. Nessas aplicações, a participação brasileira foi aumentando sem cessar, predominando, entre os anos 1885 e 1903, os empréstimos a governos. O contrário aconteceu no restante da América Latina, onde a participação relativa dos investimentos diretos britânicos tendeu a se ampliar. Uma das razões para isso foi a falta de correspondência, no caso do Brasil, entre a importância relativa dos vários fluxos financeiros e a dos vários fluxos de mercadorias oriundos dos e dirigidos aos seus vários parceiros comerciais. Como a Grã-Bretanha não era o principal destino das exportações brasileiras, os capitalistas britânicos tinham menos interesse em realizar investimentos diretos no país, preferindo aplicações de "portfólio" (Abreu, 1985). 
Felipe Amin Filomeno

A partir de 1890, intensifica-se a subordinação do Brasil à finança internacional. A ação direta dos interesses dos capitalistas estrangeiros já se fazia sentir no país há muito tempo, porém, tudo ficaria a uma grande distância do que ocorreu depois da Proclamação da República. A partir de então, a finança internacional propriamente, multiforme e ativa, e não apenas indivíduos ou inversões esporádicas de capital, vem interferir na vida brasileira procurando participação efetiva, constante e crescente em todos os setores que oferecessem oportunidades e perspectivas de bons negócios. O estabelecimento de filiais dos grandes bancos estrangeiros e o largo impulso que logo adquiriram seus negócios foram sintomas desta situação nova. Em pouco tempo, a ação progressiva dos interesses financeiros internacionais alastrou-se, infiltrando-se ativamente em todos os setores fundamentais da economia brasileira, até colocá-la em grande medida a seu serviço. A produção cafeeira, em particular (a grande atividade econômica do país), naturalmente foi logo atingida, sendo objeto de disputas entre capitalistas estrangeiros (Prado Jr., 1976).

Tudo isto trouxe um grande estímulo às atividades econômicas no Brasil, ainda que a um alto custo futuro. $\mathrm{O}$ grande incremento da lavoura cafeeira não teria sido possível sem os capitais e créditos fornecidos pela finança internacional. Como afirma Caio Prado Jr. (1976):

Boa parte dos fundos necessários ao estabelecimento de plantações e custeio da produção proveio de bancos ingleses e franceses, ou então de casas exportadoras do produto ou outros intermediários, muitos deles firmas estrangeiras ou financiadas com capitais estrangeiros (p. 210).

Em consequência da expansão da produção de gêneros tropicais e matérias-primas para os mercados mundiais, decaiu a produção de mercadorias de consumo interno, que se tornam cada vez mais insuficientes para as necessidades do país, e obrigam a importar a maior parte até dos mais vulgares artigos de alimentação. As exportações maciças compensaram, contudo, estas grandes e indispensáveis importações. Os grandes saldos comerciais obtidos a partir de então permitiram fazer frente regularmente (exceto em 1898) aos grandes compromissos externos em ascensão contínua e paralela ao desenvolvimento do país: serviço da dívida pública, pagamento de dividendos e lucros comerciais das empresas estrangeiras operando no Brasil, e, por último, as remessas de fundos feitas pelos imigrantes a seus países de origem, que começavam a tomar vulto (Prado Jr., 1976).

\subsection{A crise do Encilhamento}

Conforme afirmado acima, a política monetária que o governo imperial brasileiro mantinha não era capaz de proporcionar a liquidez necessária para fazer frente ao progresso das atividades econômicas, especialmente após a libertação 
dos escravos e a difusão do trabalho assalariado. O governo republicano buscou solucionar este problema através de uma série de reformas bancárias e monetárias voltadas a aumentar a liquidez da economia. Rui Barbosa, ministro da Fazenda do primeiro governo republicano, conservou a Lei de Reforma Bancária do Visconde de Ouro Preto, de 1888, que estabelecia os bancos de emissão, a qual não havia ainda sido implementada de maneira significativa. As disposições mais importantes desta lei eram as que se seguem.

Em primeiro lugar, bancos poderiam emitir notas conversíveis em moeda imperial, e suas emissões tinham que ser garantidas com o depósito de títulos da dívida pública e não poderiam exceder a quantia depositada em títulos. As emissões do Tesouro seriam recolhidas ante a emissão destes títulos, e os bancos, por sua vez, substituiriam os títulos do governo por ouro. Assim, inicialmente, as notas de banco seriam conversíveis em títulos governamentais; num estágio intermediário, as notas seriam conversíveis, parte em ouro, parte em títulos. E, quando todas as notas do Tesouro fossem finalmente recolhidas, as notas de banco seriam plenamente conversíveis em ouro. O resultado final pretendido era, pois, um sistema bancário com 100\% de reservas em ouro (Pelaez, 1971).

Entretanto, destinando-se inicialmente a atender às necessidades da circulação monetária em face da intensificação das transações e da vida econômica e financeira em geral, as emissões monetárias foram muito além de qualquer medida, dando origem a uma forte crise financeira, conhecida como Encilhamento $^{12}$ (que só viria a ser solucionada na virada do século). Em 1889, Rui Barbosa decretou que os bancos deveriam emitir, em três meses, a quantidade máxima de notas que lhes era permitida, o que foi feito rapidamente pela maioria deles.

Esta reforma bancária implementada no Brasil assemelhava-se àquela implementada na Argentina: enquanto lá haviam sido criados os Bancos Garantidos, aqui foram criados os Bancos Emissores. Em ambos os países, a reforma bancária estabelecia que a oferta monetária fosse descentralizada em bancos regionais e dependesse de um lastro em títulos públicos e em ouro. E, nos dois casos, o resultado foi uma expansão monetária exacerbada. Para Fausto e Devoto (2004), a própria redução do percentual mínimo de encaixes para a emissão de letras bancárias - decretada pelo Visconde de Ouro Preto na década de 1880 - já colocara o país numa situação comparada por muitos com o risco vivido pela Argentina depois de decretada a Lei dos Bancos Garantidos em 1887 e da grande emissão que ela provocou.

(12) A palavra "encilhamento" tem sua origem nas barracas do Jóquei Clube onde os cavalos eram encilhados, ou seja, apertados com cilha, arreados (porém, o verbo "encilhar", no Brasil, também quer dizer "iludir", "enganar"). Nessas barracas havia atividade intensa, apesar de elegante e na moda, tanto de apostas como de troca de palpites de apostas; daí sua associação ao clima especulativo da década de 1890. 
Felipe Amin Filomeno

O fornecimento de créditos expandiu-se e efetivou-se a reforma bancária, com a criação de vários bancos de emissão. Em apenas dois anos (1890-91) foram emitidos cerca de 335 mil contos em notas bancárias, aumentando em 1,5 vezes o saldo de papel-moeda emitido (Fausto, 1989). Efetuou-se também uma mudança nas leis de incorporação de sociedades anônimas, que completou o quadro necessário para que se iniciasse uma febre especulativa

Sob o jorro emissor, a ativação dos negócios posterior à Proclamação da República logo se converteu em especulação pura. Começam a surgir, em grande número, novas empresas de todo tipo e finalidade. Entre a data da Proclamação e o ano de 1891, incorporaram-se no Rio de Janeiro sociedades com capital global de 3 milhões de contos, enquanto é sabido que, ao iniciar-se a especulação, em novembro de 1889 , o capital de todas as sociedades existentes no país somente ultrapassava 800.000 contos. Naturalmente, a quase totalidade das novas empresas era fictícia e não tinha existência concreta, a não ser no papel. Organizavam-se apenas com o fito de emitir ações e despejá-las no mercado de títulos, onde passavam rapidamente de mão em mão em valorizações sucessivas (Prado Jr., 1976, p. 220).

Claramente, tal situação não podia durar. Em fins de 1891, estourou a crise e ruiu esse verdadeiro "castelo de cartas" levantado pela especulação. De um momento para outro, se desvanece o valor da imensa quantidade de títulos que abarrotava a bolsa e o mercado financeiro. A "débâcle", então, arrastará muitas instituições de bases mais sólidas, mas que não resistirão à crise. As falências de multiplicavam. O ano de 1892 foi de liquidação, mas ficará a herança desastrosa legada por dois anos de excessos: a massa imensa de papel inconversível em circulação. E como não foi possível estancar rapidamente este jorro emissor, a inflação ainda continuou nos anos seguintes (Prado Jr., 1976, p. 220).

Um dos fatores que estimularam as grandes emissões foi a situação do Tesouro público, junto com a perturbação produzida pela mudança do regime político, que não somente desorganizou num primeiro momento a arrecadação tributária, mas logo depois transfere para os Estados alguns tributos, com grande desfalque para as finanças nacionais. E, enquanto diminuía a receita (ou pelo menos não aumentava na devida proporção, pois uma diminuição absoluta só ocorreu de 1891 para 1892), cresciam consideravelmente os encargos com as insurreições armadas e golpes que se sucederam a partir de 1891. Na década de 1890, recursos externos foram canalizados para a repressão de revoltas que se repetiam em várias partes do país (Levy; Saes, 2001); entretanto, as condições para a contratação de empréstimos estrangeiros não eram boas. A desordem monetária, a inflação, o aumento da dívida e a depreciação cambial eram características que geravam dificuldades crescentes de acomodação junto aos Rothschild. Havia uma retração da exportação de capital pelas regiões centrais, em 
parte causada pela crise Baring. ${ }^{13}$ Os centros financeiros do exterior não só suspendiam novas remessas de capitais para o Brasil, como ainda liquidavam apressadamente suas disponibilidades locais, forçando a baixa da moeda nacional (o mil-réis). Além disso, como o país se encontrava financeira e politicamente convulsionado, não estava em posição de apelar para o crédito externo. Por isso, para cobrir o déficit orçamentário crescente, o governo não teve outro recurso que as emissões de papel inconversível. (Prado Jr., 1976, p. 221).

Assim, caiu-se num círculo vicioso: a emissão monetária exercia pressão sobre o câmbio, que se desvalorizava sob o impacto da escassez de divisas, aumentando a inflação e o serviço da dívida externa em moeda nacional, tornando ineficazes as medidas de correção dos desequilíbrios financeiros, agravando o clima de insatisfação política e implicando maiores gastos do governo e novas emissões monetárias. Desse modo, o déficit orçamentário, o desequilíbrio das contas externas do país e as emissões imoderadas provocaram uma rápida desvalorização da moeda nacional. Segundo Prado Jr. (1976), ao proclamar-se a República, o câmbio cotava-se na taxa de 27 dimes por mil-réis; no curso do ano de 1892, oscilará entre 16 e 10 dimes. E a seguir, embora tivesse desaparecido sua causa inicial (que fora a especulação de 1890-91), a circulação aumenta dos 561 mil contos, em 1892, para um máximo de 780 mil contos em 1898. Neste mesmo período, o câmbio descerá para o nível ínfimo de menos de 6 dimes, complicando cada vez mais a situação (Prado Jr., 1976, p. 221).

Em 1895, os Rothschild concederam outro empréstimo ao Brasil, a fim de prover recursos para o serviço da dívida externa e evitar maiores pressões sobre a taxa de câmbio, envolvendo cláusulas de condicionalidade, alienação de receitas e demanda por um governo conservador. ${ }^{14}$ Em consequência da crise do Encilhamento, a coligação nacionalista do governo provisório perdeu o controle do Estado em 1894, sendo obrigada a reprimir uma rebelião da Marinha e outra no Rio Grande do Sul. Os governos que se seguiram foram muito menos intervencionistas do que os dos nacionalistas (Dean, 2002).

Ainda outro problema surgiria para agravar essa situação. Nos primeiros anos da República houve uma grande expansão da economia cafeeira, que consolidou o predomínio dos empresários do café. Em uma época em que a intervenção governamental no mercado não era necessária, a política monetária e seus reflexos cambiais dos primeiros governos republicanos representaram, em

(13) "O desafortunado estado de coisas que recentemente se tem observado na República Argentina teve um efeito deplorável sobre todos os papéis e sobre todas as questões financeiras relacionadas aos estados sulamericanos" (resposta dos Rothschild ao pedido de apoio financeiro do governo brasileiro). (FRANCO, 1989).

(14) "Seria impossível para nós tentar colocar um grande empréstimo brasileiro, exceto se medidas forem tomadas ao mesmo tempo para se elevar as receitas e reduzir as despesas do Brasil" (carta dos Rothschild ao governo brasileiro em 1895) (Franco, 1989). 
curto prazo, um poderoso incentivo ao avanço da cafeicultura (Fausto, 1989). Estimulados pela onda de investimentos externos nos anos que se seguiram a 1885 (parte de um processo sistêmico de exportação de capital pelo centro que, como se viu, afetava também a Argentina), e pelo dinheiro barato do governo republicano provisório, os novos plantios em São Paulo dobraram os cafezais do Brasil. Como resultado, em 1896, o café brasileiro enfrentaria dificuldades comerciais. Os preços declinavam e estoques invendáveis começavam a se acumular, pois estavase diante de uma situação de superprodução. Nos primeiros anos da queda de preços a situação ainda se dissimulará, em parte com a desvalorização da moeda brasileira; em moeda nacional, o preço do café não oscilará muito. Ao final, o maior responsável pela crise era o aumento das culturas (Prado Jr., 1976, p. 229). Vale lembrar que, na Argentina, anos antes, a queda do preço mundial do trigo fora também um fator importante no desencadeamento da crise Baring.

Nas palavras de Prado Jr. (1976),

A todos estes fatores acrescenta-se um último que vem agravar fortemente as dificuldades: é a ação perturbadora da finança internacional que procura se imiscuir e penetrar cada vez mais profundamente na vida econômica do país. O momento lhe era favorável, pois as dificuldades políticas e financeiras do governo abriam-lhe caminho para junto dele e lhe proporcionavam posições seguras. Forçará, entre outros expedientes, empréstimos e compromissos onerosos; o desequilíbrio financeiro, tanto interno como das contas internacionais, dará ampla margem para especulação. O jogo de câmbio, em particular, será fácil e largamente proveitoso (p. 221).

Assim como a crise Baring levou à maior subordinação do Estado argentino às altas-finanças internacionais, a crise do Encilhamento também levou o Estado brasileiro à sujeição aos ditames das grandes casas financeiras, especialmente (como será visto adiante) entre 1898 e 1902. Mas, conforme Dean (2002), já a partir de 1894 a preocupação dominante dos governos civis foi mostrar aos banqueiros estrangeiros que eram merecedores de crédito.

Neste momento, a finança internacional consolidou suas posições, fortes e sólidas, no terreno da maior riqueza do país: o comércio do café - o qual passou daí por diante a ser estreitamente controlado em função dos seus interesses. Isto já aparecia claramente por ocasião da crise cafeeira de 1896 (acima referida). O aumento da produção foi aproveitado para forçar a baixa do preço do produto, que declinou daí por diante em até 50\%; contudo, com o controle do comércio e da exportação, impediu-se que os excessos chegassem até os mercados consumidores, onde o preço se manteve sem modificação. Os intermediários, que em última instância eram agentes diretos ou indiretos da finança internacional, ganharam assim grossas diferenças. Esta sorte de especulação com o grande gênero da produção brasileira se repetiu depois e de várias formas, mas sempre com o mesmo resultado, a saber: tirar do produto brasileiro o máximo - e um máximo 
que representava porcentagem considerável do seu valor efetivo (Prado Jr., 1976, p. 222). Como ocorrido no país vizinho, a influência dos estrangeiros sobre elos importantes da cadeia mercantil dos produtos de exportação dificultava a retenção do excedente econômico local, agravando as crises econômicas.

Nenhuma melhora na situação cambial se observaria ao longo de 1896 e 1897, sendo o empréstimo concedido pelos Rothschild, em 1895, consumido rapidamente, e ainda tendo o governo brasileiro contraído novos empréstimos de curto prazo para evitar pressões adicionais sobre o mercado de câmbio. Os banqueiros insistiam que a única forma de o governo obter fundos seria através de uma proposta de arrendamento da Cia. Estrada de Ferro Central do Brasil. As crises cambiais (uma em 1891/92 e outra em 1898) agravaram ainda mais o déficit orçamentário, pois o governo era forçado a tomar mais empréstimos para pagar a dívida externa, que se tornava mais onerosa com a depreciação da moeda, e para evitar que esta se depreciasse ainda mais.

A interrupção do fluxo de capitais estrangeiros e do impulso dinâmico da demanda mundial por café havia desencadeado uma crise generalizada, tal como afirmado na teoria dos ciclos de endividamento. A moeda em circulação, o câmbio e a dívida externa quase quadruplicaram de 1889 a 1898. O total de papel-moeda em circulação aumentou de 211 para 779,9 mil contos, o câmbio de $9 \$ 078$ para 33\$391 mil-réis por libra esterlina e, apesar da dívida externa em libras ter crescido apenas $18 \%$, passando de 30,4 para 35,7 milhões (uma taxa muito menor do que no período 1882/1889), a dívida em moeda nacional passou de 275,5 em 1889 para 1.193,1 mil contos em 1898 (Orair, 2002, p. 38).

A desvalorização cambial representava uma transferência de renda daqueles que pagavam as importações para aqueles que vendiam as exportações. Como as importações eram pagas pela coletividade, os empresários exportadores estavam, na realidade, socializando as perdas que tendiam a se concentrar em seus lucros (Furtado, 1998). Dessa forma, o papel periférico (economia agroexportadora) desempenhado pelo Brasil na economia-mundo, que gerou uma tendência estrutural ao desequilíbrio no balanço de pagamentos que pressionava o câmbio (da Proclamação da República à crise de 1929, verificou-se uma tendência secular de depreciação da moeda nacional), condicionava o país a uma concentração de renda em favor dos grandes latifundiários exportadores nas fases de crise.

Todas estas dificuldades somadas levam o país à bancarrota em 1898. As falências se multiplicavam e o Tesouro não conseguia mais fazer frente a seus compromissos, pois as receitas não chegavam a cobrir nem a metade da despesa. Finalmente, o governo brasileiro declarou moratória em 1898/1900 e um plano de refinanciamento (conhecido como "funding loan") foi acertado após os banqueiros 
internacionais terem recebido a proposta de moratória. Os termos do acordo eram re-financiar o serviço da dívida pública externa e algumas garantias de juros, em troca de medidas de saneamento fiscal e monetário. Segundo Franco (1989), o "funding loan" gozaria de garantias especiais: uma primeira hipoteca sobre as receitas em moeda forte da Alfândega do Rio de Janeiro e o compromisso de que o governo agisse firmemente no nível monetário e fiscal. A gravidade da situação era tal que, quando Campos Salles assumiu o governo, em 1898, a taxa de câmbio estava cotada em 7 pence. Para receber o "funding loan", Campos Salles prometeu não emitir mais papel-moeda e exercer uma política econômica conservadora. $\mathrm{O}$ governo se esforçou em manter o país conectado à comunidade financeira internacional e capitais externos afluíram para o Brasil nos três anos de moratória, demonstrando a confiança dos investidores na gestão econômica do país. O acordo era semelhante ao realizado pela Argentina em 1891, envolvendo também garantias ferroviárias, alienação de receitas alfandegárias e o compromisso de não assumir empréstimos externos adicionais. Tais aspectos confirmam o pensamento de Abreu (2002), segundo o qual a inspiração argentina do "funding loan" brasileiro é clara.

De acordo com Franco (1989), no orçamento de 1900, várias despesas foram reduzidas, especialmente as denominadas em moeda estrangeira, e a tributação foi efetivamente elevada através de diversas medidas de modernização administrativa e também através de aumentos nos impostos, destacadamente no imposto de consumo e do selo. Campos Salles e seu ministro da fazenda, Joaquim Murtinho, reduziram as despesas com militares e procuraram compradores ou locatários para as ferrovias do governo. A folha de pagamento do governo manteve-se estável, enquanto alguns funcionários públicos eram demitidos por não comparecimento ao trabalho. As pensões públicas foram limitadas e empréstimos oficiais aos latifundiários foram negados. Murtinho também aumentou a coleta de impostos sobre importações, então a maior fonte de receita do governo, e alugou algumas das ferrovias do governo a companhias privadas. Privatizando as ferrovias, o governo de Campos Salles reduziu o papel do Estado na economia e, por ser contra a intervenção estatal, evitou socorrer os cafeicultores. Na gestão de Murtinho, quase metade do orçamento destinava-se a provisões para pagamento da dívida, sendo o segundo maior destino de recursos públicos o Ministério da Indústria, Transporte e Obras Públicas, que viu seus recursos grandemente reduzidos (Franco, 1989).

A política econômica do ministro Murtinho, que consistiu na execução do esquema do "funding loan", tinha seu núcleo na redução do papel-moeda em circulação. Até maio de 1903, o papel-moeda destruído somaria 13\% do total em 1898, o que provocou falências bancárias em 1900 (o meio circulante caíra de 733 
milhões de milréis em 1898 para 675 milhões em 1902). Neste ano, o Banco da República faliu, devendo a quantia de 1 milhão de libras ao governo.

Para fortalecer a iniciativa privada, o Estado abdicara de seu direito, existente desde 1892, de nomear o presidente do Banco da República, então a instituição mais próxima de um banco central. Porém, como condição para fornecer ajuda ao banco, Campos Salles e Murtinho insistiram na nomeação de Otto Petersen, gerente de um banco alemão, como diretor do Banco da República, tendo recebido, por isso, oposição nacionalista.

No Rio, sete bancos, além do Banco da República, se reorganizaram ou foram liquidados em 1900. Essas instituições tinham créditos inadimplentes em suas carteiras desde o Encilhamento e foram afetadas pela ortodoxia monetária. Como sinal de contentamento pela forma na qual Campos Salles contornou a crise bancária, os títulos da dívida brasileira se apreciaram. A re-organização monetária gerou deflação, capitais externos ingressaram no país e a moeda apreciou-se, recuperando parte de seu valor.

Segundo Franco (1989), a revitalização das entradas de capital, observada a partir da adoção do programa conservador, revela a influência da percepção dos mercados financeiros internacionais sobre o curso da política econômica do país. Para o mesmo autor, porém, não é claro, a priori, em que medida a apreciação se devia à contração monetária ou a fatores exógenos associados ao balanço de pagamentos, tais como o crescimento das exportações de borracha, por exemplo. A tabela abaixo apresenta dados sobre a contração monetária e a apreciação cambial no período:

Tabela 3

Meio circulante e taxa de câmbio no Brasil (1898-1902)

\begin{tabular}{l|c|c|c}
\hline \multirow{2}{*}{ Anos } & \multirow{2}{*}{ Papel-moeda em circulação } & \multicolumn{2}{|c}{$\begin{array}{c}\text { Taxa de câmbio } \\
\text { (libra esterlina/mil-réis) }\end{array}$} \\
\cline { 2 - 4 } & & Máxima & Mínima \\
\hline 1898 & $780.765: 423 \$ 000$ & 8 e $1 / 2$ & 5 e $53 / 64$ \\
\hline 1899 & $733.727: 153 \$ 000$ & 8 e $5 / 32$ & 6 e $27 / 32$ \\
\hline 1900 & $699.631: 719 \$ 000$ & 12 e $3 / 52$ & 7 e $1 / 2$ \\
\hline 1901 & $680.451: 058 \$ 000$ & 12 e $1 / 12$ & 10 \\
\hline 1902 (até junho) & $679.450: 443 \$ 000$ & 12 e $1 / 14$ & 11 e $5 / 18$ \\
\hline
\end{tabular}

Fonte: Guanabara (1983).

A revalorização da moeda trouxe dificuldades para a indústria nacional. Porém, a política de saneamento a compensou com um fator que, sobretudo no futuro, foi de grande significação: a cobrança em ouro de uma porcentagem dos direitos alfandegários - a chamada "cláusula ouro". Esta medida, adotada para permitir ao Tesouro público fazer face a seus grandes compromissos externos sem 
sofrer as contingências das oscilações cambiais, representará desde logo um acréscimo considerável de tarifas, pois o mil-réis-ouro valia 27 dimes, contra 15 dimes para o papel. E funcionaria no futuro como um reforço da barreira tarifária em consequência de qualquer nova depreciação cambial, o que, aliás, se verificará continuamente daí por diante (Prado Jr., 1976). A indústria concentrou-se grandemente em São Paulo, aumentando as desigualdades regionais do país. A riqueza e a população trazidas pela lavoura cafeeira (incluindo a população imigrante com habilitação técnica superior à do trabalhador nacional recémegresso da escravidão) tornavam aquele Estado mais atrativo para os investimentos industriais.

As medidas deflacionárias fiscais e monetárias incidiram negativamente sobre algumas empresas estrangeiras já estabelecidas no país. No caso das empresas ferroviárias, os impactos dessas medidas não apenas se resumiam ao agravamento da recessão, mas também à perda de privilégios estatais (as garantias de juros foram suspensas no período 1898/1900). Emergiu um conflito entre empresas ferroviárias estrangeiras e a nova orientação da política econômica, acordada entre o Estado e os credores internacionais. A solução desse impasse foi uma operação de empréstimo externo em 1901 (£16.619.320), destinado à encampação de todas as estradas de ferro que possuíssem garantias de juros (Orair, 2002). ${ }^{15}$

De acordo com Prado Jr. (1976, p. 223), o grande beneficiário das reformas de 1898, embutidas no pacote do "funding loan", foi sem dúvida a finança internacional, representada neste caso pelo London \& Riverplate Bank, que ganhou novas posições no Brasil e junto ao seu governo. Os seus representantes assumirão o direito de velarem diretamente pelo cumprimento das medidas destinadas a restaurar as finanças do país. Entrelaçam-se, assim, intimamente seus interesses e suas atividades com a vida econômica e administrativa brasileira. Para o mesmo autor, "consolidara-se uma situação de dependência que se vinha formando havia muito, mas que somente agora encontrará seu equilíbrio definitivo. O Brasil se torna um largo e seguro campo para a inversão de capitais, estes encontrarão melhor acolhida, e abrir-se-ão para eles as mais vantajosas aplicações" (Prado Jr., 1976, p. 223). Posteriormente, o capital estrangeiro regressaria ao país:

Efetivamente o capital estrangeiro voltará a fluir para o Brasil em proporções consideráveis. E isto permitirá não somente restabelecer o equilíbrio das contas externas, mas fazê-lo em um nível muito alto. Instalar-se-ão grandes e modernos

(15) Esta operação, permitida excepcionalmente pelos Rothschild, foi favorável às finanças estatais, pois as garantias de juros das empresas variavam de 6 a $9 \%$ e foram substituídas por um empréstimo com juros de 5\%, fora o produto do arrendamento dessas estradas destinado, em muitos casos, para as próprias companhias que as operavam anteriormente (Orair, 2002). 
portos, a rede ferroviária crescerá rapidamente, inauguram-se as primeiras usinas de produção de energia elétrica, remodelam-se com grandes obras as principais cidades [...] Para isto contribuirá também o forte incremento da produção e das exportações [...] que fornecerão ao país outras largas disponibilidades para satisfação de seus pagamentos no exterior [...] São estes dois fatores - a situação folgada no comércio internacional e o reforço das inversões de capital estrangeiro que permitirão ao Brasil equilibrar sua vida financeira e consolidar sua posição econômica (Prado Jr., 1976, p. 223-224).

Contudo, o país continuará a ser um produtor de uns poucos gêneros de grande expressão no comércio mundial.

Assim, após o "funding loan" de 1898, houve um temporário desafogo do balanço de pagamentos. Com a suspensão das obrigações decorrentes da dívida, a cobrança em ouro de parte do imposto de importação, o gradativo aumento do volume das exportações e a contenção das importações, o câmbio se valorizou a partir de 1899. Ao mesmo tempo, os preços mundiais do café caíam. Esses dois movimentos afetavam negativamente a renda dos cafeicultores. Portanto, havia um aparente paradoxo entre a política econômico-financeira ortodoxa dos presidentes paulistas Prudente de Morais, Campos Salles e Rodrigues Alves, e o predomínio da burguesia do café e sua hegemonia no plano nacional. Como explicar que os representantes políticos de uma classe hegemônica se comportassem no governo de forma aparentemente contrária a seus interesses? (Fausto, 1989).

Para Fausto (1989), as medidas de contenção tomadas, sobretudo pelo governo Campos Salles (mas ensaiadas desde 1891), pareciam corresponder a uma tentativa de restaurar o equilíbrio entre demanda e oferta, rompido nos anos anteriores, recorrendo à deflação e ao profundo corte das despesas governamentais. Esta política, assim como o "funding loan", traria como consequência a elevação da taxa cambial, objetivo visado diretamente pelos credores externos, interessados em assegurar as condições para o pagamento futuro da dívida. Ainda que não se possa falar de uma única alternativa para os problemas econômico-financeiros do período, é duvidoso imaginar, nos limites da época, uma resposta que não passasse pelos caminhos da depressão e da concordância com as imposições dos credores. Neste sentido, a classe hegemônica local perseguia objetivos universais, ao sustentar o funcionamento de certo tipo de Estado nacional, como condição de sua própria hegemonia. O sacrifício de alguns setores da própria classe era inevitável, mas isto não pressupunha, é claro, o colapso de toda cafeicultura (Fausto, 1989).

Além disso, segundo Furtado (1998, p. 172), com a abolição da escravatura e a proclamação da República, os interesses diretamente ligados à depreciação externa da moeda nacional - grupos exportadores - passaram a 
enfrentar a resistência organizada de outros grupos, tais como a classe média urbana (empregados do governo, civis e militares, e do comércio) os assalariados urbanos e rurais, os produtores agrícolas ligados ao mercado local, e as empresas estrangeiras que exploravam serviços públicos (das quais nem todas tinham garantia de juros). Os nascentes grupos industriais, que estavam mais interessados em aumentar a capacidade produtiva (através da importação de equipamentos) do que em obter proteção adicional, também se sentiam prejudicados com a depreciação cambial. Assim, se por um lado a descentralização política promovida pela República em favor dos Estados federados favoreceu os interesses da classe agrícola-exportadora, por outro a ascensão política de novos grupos sociais veio reduzir o controle que esta exercia sobre o governo central. Considerando as já mencionadas relações da abolição e da imigração com a conjuntura sistêmica, pode-se afirmar que havia um vínculo entre a alteração na correlação local de poder entre os diversos grupos sociais - conforme observado por Prado Jr. (1976) - e a dinâmica da economia-mundo.

As relações entre a crise do Encilhamento e a conjuntura da economiamundo também foram exploradas por Caio Prado Jr. (1976), que interpreta a crise e seus desdobramentos como o efeito de um esforço de adaptação do país à conjuntura mundial do final do século XIX. A abolição da escravidão e a consequente transformação do regime de trabalho (com a imigração estrangeira como corolário), a Proclamação da República (em parte consequência da abolição) e a consolidação do domínio da finança internacional na vida econômica do país foram passos preliminares e preparatórios que ajustaram o Brasil ao equilíbrio mundial marcado pelo imperialismo financeiro. Da súbita irrupção destes fatores na vida brasileira decorreram as perturbações sofridas. Mas, aos poucos o país se afeiçoará à nova situação, ajustando suas relações internacionais e recompondo seus quadros econômicos e políticos locais (Prado Jr., 1976, p. 224).

Em comparação com a Argentina, o papel das emissões no deflagrar da crise parece ter sido maior no Brasil, pois estas se verificaram, por razões institucionais e em consequência das transformações sociais que se operavam no país (abolição da escravatura, imigração europeia), somente no início da década de 1890, quando a entrada de capitais estrangeiros já começara a declinar. Embora as inversões inglesas crescessem no Brasil em um ritmo muito inferior ao da Argentina nos anos 1880, elas ascenderam de 38,9 milhões de libras esterlinas em 1880 para 68,7 milhões em 1890. Na década de 1890, as inversões se deram em um ritmo muito menor, em parte pelo efeito de contágio gerado pela crise Baring. Entre 1890 e 1892, por exemplo, o Brasil não obteve nem um único empréstimo estrangeiro novo (Fausto, 1989). 
O curto "boom” brasileiro do início dos 1890 geraria pressões por ações importadoras que não puderam ser atendidas, nem pelos empréstimos estrangeiros, nem por um correspondente incremento das exportações. Entre as causas destas pressões se encontra a maior dependência, com relação ao exterior, do suprimento interno de gêneros alimentícios, em decorrência do deslocamento crescente de recursos locais para a lavoura cafeeira. É em conexão com este quadro que se deve compreender a contínua desvalorização cambial iniciada em 1890. A recessão que se esboçava em 1891 foi até certo ponto adiada pelo fato de que, embora os preços mundiais do café começassem a cair desde 1890 (ao contrário do que sucedeu com os produtos de exportação argentinos), sua queda não chegou a se tornar mais séria senão por volta de 1894, quando a recessão iniciada na Europa atingiu os EUA (Fausto, 1989).

Além disto, como se afirmou acima, a partir da safra de 1896-97, os cafezais plantados no período de euforia começaram a produzir, resultando em uma grande ampliação da oferta brasileira, num momento em que os preços tendiam a declinar. Apesar da ampliação das exportações, a receita de divisas provenientes do café caiu seguidamente a partir de 1896, agravando ainda mais o problema do balanço de pagamentos. Por sua vez, os novos empréstimos obtidos em meados da década se destinaram a cobrir déficits orçamentários, em meio a uma situação difícil, na qual o serviço da dívida externa consumia cerca de $80 \%$ dos saldos da balança comercial. Não obstante as diferenças cronológicas, entre outras que resultam da especificidade de cada país, as semelhanças entre os casos, o desequilíbrio entre expansão das exportações e as pressões por importar, o peso representado pela dívida externa e a retração do capital estrangeiro foram elementos essenciais da crise (Fausto, 1989, p. 205), conforme estabelece a teoria dos ciclos de endividamento dos Estados periféricos e semiperiféricos.

Assim, o colapso cambial de 1890-92 foi seguido, após um período de grande instabilidade econômica local e crônico desequilíbrio externo, por negociações com banqueiros internacionais visando à obtenção da liquidez necessária ao restabelecimento do equilíbrio cambial, como pré-condição para adoção simultânea de um programa ortodoxo de estabilização. Foi dessa situação de penúria cambial e grande dependência em relação aos banqueiros internacionais que resultaram as políticas monetárias e fiscais extremamente restritivas do governo Campos Salles (Fritsch, 1985), um enredo bastante semelhante ao da crise Baring.

Posteriormente, o aumento do valor das exportações, decorrente da produção de borracha e de café, contribuiria para a recuperação econômica do país e a superação da crise - ainda em acordo com a teoria dos ciclos mundiais de endividamento. A Tabela 4 sintetiza a evolução de indicadores econômicos importantes no período. 
Felipe Amin Filomeno

Tabela 4

Sumário da evolução de indicadores econômicos do Brasil (1886-1897)

\begin{tabular}{|c|c|c|c|c|}
\hline Ano & $\begin{array}{l}\text { PIB (preços de } \\
\text { 1910, milhões } \\
\text { de mil-réis) }^{\text {(a) }}\end{array}$ & $\begin{array}{c}\text { Saldo da balança } \\
\text { comercial (FOB) } \\
\text { (milhares de libras) }^{(b)}\end{array}$ & $\begin{array}{l}\text { Pagamento de juros - } \\
\text { balanço de } \\
\text { pagamentos (milhares } \\
\text { de libras) }{ }^{\text {(c) }}\end{array}$ & $\begin{array}{c}\text { Preço do café } \\
\text { (US\$ cents/lb) }^{(\mathrm{d})}\end{array}$ \\
\hline 1886 & & -196 & -692 & \\
\hline 1887 & & 4.382 & -1.339 & \\
\hline 1888 & 3.150 & 1.990 & -1.188 & \\
\hline 1889 & 3.239 & 4.550 & -1.414 & 16 \\
\hline 1890 & 3.619 & 2.363 & -1.963 & 19 \\
\hline 1891 & 3.929 & 1.571 & -2.044 & 20 \\
\hline 1892 & 3.490 & 4.552 & -2.014 & 14 \\
\hline 1893 & 3.043 & 5.792 & -2.352 & 16 \\
\hline 1894 & & 3.346 & -2.400 & \\
\hline 1895 & & 3.374 & -2.482 & \\
\hline 1896 & & 453 & -3.020 & \\
\hline 1897 & & 2.893 & -3.019 & \\
\hline
\end{tabular}

Fontes: (a) Goldsmith (1986 apud Triner, 2001); (b) IBGE (1990 apud IBGE, 2003); (c) Franco (1988); (d) Fritsch (1988 apud Triner, 2001).

\section{Considerações finais}

A análise comparativa realizada permite concluir que as duas crises não foram apenas resultados nefastos de políticas econômicas irresponsáveis implementadas de modo semelhante por dois Estados vizinhos. A relação dos dois países com a economia mundial, marcada pelo seu caráter periférico e pelo seu papel de agroexportador na divisão mundial do trabalho, foi um elemento importante na gestação da crise. A influência das oscilações dos fluxos mundiais de capital (decorrentes de problemas nos países centrais), a dificuldade em aderir ao padrão-ouro e o comportamento especulativo dos financistas internacionais (capaz de gerar o "contágio" da crise de um país para outro) atestam isso. Ademais, não apenas a gestação das crises esteve relacionada a processos sistêmicos, mas também a recuperação econômica posterior foi assegurada especialmente por uma maior demanda mundial por produtos primários produzidos nos dois países. Assim, demonstra-se que as causas das crises Baring e do Encilhamento não estão encerradas nas políticas econômicas de curto prazo implementadas pelos Estados argentino e brasileiro, ou no comportamento imediato dos investidores estrangeiros naquele período, posto que ambas são partes integrantes de processos sistêmicos mais amplos - fluxos mundiais de capital/ciclos mundiais de endividamento - que devem ser considerados na explicação das crises. 


\section{Referências bibliográficas}

ABREU, Marcelo de Paiva. A dívida pública externa do Brasil, 1824-1931. Estudos Econômicos, São Paulo, v. 15, n. 2, 1985.

Os funding loans brasileiros - 1898-1931. Pesquisa e Planejamento Econômico, v. 32, n. 3, dez. 2002.

BÓZZOLI, Guillermo; DELLA PAOLERA, Gerardo; IRIGOIN, Maria Alejandra. Passing the Buck: monetary and fiscal policies in Argentina: 1852-2000. In: DELLA PAOLERA, Gerardo; TAYLOR, A. M. (Ed.). A new economic history of Argentina. Cambridge: Cambridge University Press, 2003.

CORTÉS CONDE, Roberto. La economia argentina en el largo plazo (siglos XIX y XX). Buenos Aires: Editorial Sudamericana / Universidad de San Andrés, 1997.

DEAN, Warren. A economia brasileira, 1870-1930. In: BETHELL, Leslie (Org.). História da América Latina: de 1870 a 1930, v. V. São Paulo: Editora da Universidade de São Paulo/ Imprensa Oficial do Estado; Brasília: Fundação Alexandre de Gusmão, 2002.

DELLA PAOLERA, G. Experimentos monetarios y bancarios en Argentina: 1861-1930. Revista de Historia Económica: Nuevos enfoques en la Historia Económica de España y America Latina, Madrid, Alianza Editorial Universidad Carlos III, Año 12, n. 3, Otoño 1994.

FAUSTO, Boris. Expansão do café e política cafeeira. In.: FAUSTO, Boris (Org.). História geral da civilização brasileira. III. O Brasil Republicano. 1. Estrutura de poder e economia (1889-1930). Rio de Janeiro: Bertrand Brasil S.A., 1989.

; DEVOTO, Fernando J. Brasil e Argentina: um ensaio de história comparada (1850-2002). São Paulo: Editora 34, 2004.

FRANCO, Gustavo H. B. O balanço de pagamentos do Brasil, 1870-1900. Rio de Janeiro: PUC. Departamento de Economia, 1988. (Texto para discussão, 201). Disponível em: $<$ www.ipeadata.gov.br $>$.

A primeira década republicana. In: ABREU, Marcelo de Paiva (Org.). A ordem do progresso: cem anos de política econômica republicana, 1889-1989. São Paulo: Campus, 1989.

Há cem anos atrás. O Estado de São Paulo, São Paulo, 2 jan. 2000.

FRITSCH, Winston. Sobre as interpretações tradicionais da lógica da política econômica na Primeira República. Estudos Econômicos, São Paulo, v. 15, n. 2, 1985.

FRITSCH, W. External constraints on economic policy in Brazil, 1889-1930. Pittsburgh: University of Pittsburgh Press, 1988 apud Triner (2001).

FURTADO, Celso. Formação econômica do Brasil. São Paulo: Companhia Editora Nacional, 1998. (primeira edição: 1959).

GOLDSMITH, R. Brasil 1850-1984: desenvolvimento financeiro sob um século de inflação. São Paulo: Banco Bamerindus / Ed. Harper Row do Brasil, 1986 apud Triner (2001).

GUANABARA, Alcindo. A presidência Campos Sales. Brasília: Editora UNB, 1983. 
IBGE. Estatísticas históricas do Brasil: séries econômicas, demográficas e sociais de 1550 a 1988. 2. ed. rev. e atual. do v. 3 de "Séries estatísticas retrospectivas". Rio de Janeiro: IBGE, 1990 apud IBGE. Estatísticas do século XX, Centro de documentação e disseminação de informações. Rio de Janeiro: IBGE, 2003. Disponível em:

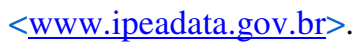

JONES, C. A. British capital in Argentine history: structures, rhetoric and change. In.: HENNESSY, A.; KING, J. The land that England lost. London: British Academic, 1992.

LENZ, Maria Heloisa. Crescimento econômico e crise na Argentina de 1870 a 1930: a Belle Époque. Porto Alegre: Editora da UFRGS/ Fundação de Economia e Estatística Sigfried Emanuel Heuser, 2004.

LEVY, Maria-Bárbara; SAES, Flávio A. M. de. Dívida externa brasileira, 1850-1913: empréstimos públicos e privados. História Econômica \& História de Empresas, v. IV, n. 1, 2001.

LUXEMBURGO, Rosa. A acumulação do capital. São Paulo: Abril Cultural, 1984. v. II.

MARICHAL, Carlos. Historia de la deuda externa de América Latina. México, D.F.: Allianza Editorial Mexicana, 1988.

NASSIF, Luís. Os cabeça-de-planilha: como o pensamento econômico da era FHC repetiu os equívocos de Rui Barbosa. Rio de Janeiro: Ediouro, 2007.

ORAIR, Rodrigo O. Dívida externa brasileira e financiamento ao "subdesenvolvimento" (1824-1914). Monografia (Graduação)-Universidade Federal de Minas Gerais (UFMG). Faculdade de Ciências Econômicas, Belo Horizonte, 2002. 52p.

PELAEZ, Carlos Manuel. As consequências econômicas da ortodoxia monetária, cambial e fiscal no Brasil entre 1889-1945. Revista Brasileira de Economia (3/71), 1971.

PRADO JR., Caio. História econômica do Brasil. São Paulo: Brasiliense, 1976 (primeira edição: 1945).

RAPOPORT, Mario. Historia económica, política y social de la Argentina (1888-2000). Buenos Aires: Ediciones Macchi, 2003.

REGALSKY, Andrés. Endeudamiento, finanzas públicas y balanza de pagos en la Argentina (1880-1914). In.: BOVKYNE, S. V.; BRODER, A.; MARANHAO, R. Public debt, public finance, money and balance of payments in debtor countries, 1890-1932/33. Sevilla, 1998.

Banca y capitalismo en la Argentina, 1850-1930: un ensayo crítico. Ciclos en la Historia, la Economia e la Sociedad, Buenos Aires, v. 9, n. 18, 1999.

ROCK, David. Racking Argentina. New Left Review, 17, set./out. 2002.

ROMERO, Luis Alberto. Breve historia contemporánea de la Argentina. Buenos Aires: Fondo de Cultura Económica de Argentina S. A., 2001.

SAES, Flávio A. M. de; SZMRECSÁNYI, Tamás. O capital estrangeiro no Brasil, 18801930. Estudos Econômicos, São Paulo, v. 15, n. 2, 1985.

SIMON, M. The pattern of new British portfolio foreign investment, 1865-1914. In: ADLER, J. H. (Ed.). Capital movements and economic development. London: Macmillan 
1967/1968. Reprinted in: HALL, A. R. (Ed.). The export of capital from Britain, 18701914. London: Methuen, 1990.

SIMON, M. Cyclical fluctuations in the international capital movements of the United States, 1865-1895. Thesis (Doctoral)-Columbia University. Published by New York: Arno, 1955 [1978],

STEWART, Taimoon. The third world debt crisis: a long waves perspective. Review (Fernand Braudel Center), XVI, 2, Spring, 1993.

SUTER, Christian. Debt cycles in the world-economy: foreign loans, financial crisis and debt settlements, 1820-1990. Oxford: Westview Press, 1992.

SUTER, C.; PFISTER, U. International financial relations as part of the world-system. International Studies Quarterly, 31, 1987.

TANNURI, Luis Antonio. O encilhamento. São Paulo: Hucitec, 1981.

TILLY, C. Big structures, large processes, huge comparisons. New York: Russel Sage Foundation, 1984.

TORNQUIST, E. El desarrollo económico de la República Argentina en los últimos cincuenta años. Buenos Aires: E. Tornquist, 1920.

TOUSSAINT, Eric. Las crisis de la deuda externa de América Latina en los siglos XIX e XX. CADTM, 2003. Disponível em: <www.cadtm.org $>$.

TRINER, Gail D. International capital and the Brazilian encilhamento, 1889-1891: an early example of contagion among emerging capital markets? Rutgers University. Department of History, 2001.

WILLIAMS, John H. La crisis y el Banco Baring, 1890-1891. Revista de Ciencias Económicas, nov. 1921. 